\title{
NEW PROCEDURES OF SCIENTIFIC INVESTIGATION AND THE PROTECTION OF THE ACCUSED'S RIGHTS
}

\author{
Robinson O. Everett*
}

\section{INTRODUCTION}

THE ONWARD march of science has provided police officials with 1 new weapons in the battle against crime. Yet, the risk that these same weapons will be unloosed against civil liberties has long disturbed many American jurists. Thus, in 1928, inveighing against wire tapping, Justice Brandeis commented: ${ }^{I}$

The progress of science in furnishing the Government with means of espionage is not likely to stop with wire tapping. Ways may some day be developed by which the Government, without removing papers from secret drawers, can reproduce them in court, and by which it will be enabled to expose to a jury the most intimate occurrences of the home. Advances in the psychic and related sciences may bring means of exploring unexpressed beliefs, thoughts and emotions. "That places the liberty of every man in the hands of every petty officer" was said by James Otis of much lesser intrusions than these. To Lord Camden, a far slighter intrusion seemed "subversive of all the comforts of society." Can it be that the Constitution affords no protection against such invasions of individual security?

To Brandeis, the invasion of privacy produced by wire tapping brought it within the Constitution's proscription of unreasonable searches and

* A.B. 1947, LL.B. 1950, Harvard University. Visiting Associate Professor of Law, Duke University; Member of the North Carolina bar. Author, Military Justice IN THE.ARMEd Forces of THE UNITED STATES (1956). Contributor to legal publications.

${ }^{1}$ Olmstead v. United States, 277 U.S. 438,474 (1928). 
seizures. ${ }^{2}$ Justice Murphy, in similar language, condemned the use of another device, the detectaphone: ${ }^{3}$

There was no physical entry in this case. But the search of one's home or office no longer requires physical entry, for science has brought forth far more effective devices for the invasion of a person's privacy than the direct and obvious methods of oppression which were detested by our forebears and which inspired the Fourth Amendment. Surely the spirit motivating the framers of that Amendment would abhor these new devices no less. Physical entry may be wholly immaterial. Whether the search of private quarters is accomplished by placing on the outer walls of the sanctum a detectaphone that transmits to the outside listener the intimate details of a private conversation, or by new methods of photography that penetrate walls or overcome distances, the privacy of the citizen is equally invaded by agents of the Government and intimate personal matters are laid bare to view.

Obviously these warnings by Justices Brandeis and Murphy deserve attention; one cannot underestimate the danger that, in warring against crime, democratic institutions may be endangered.

Yet the contributions of science are not solely in police hands. They can be quite useful to the enemy of society. For instance, devices for electronic eavesdropping can be valuable to the blackmailer or the spy. Or, more fundamentally, the instrumentalities of modern living which the scientist has furnished us may be potent aids to crime. Automobiles and airplanes afford the mobility that may shield the criminal from detection or capture. ${ }^{4}$ Telephones and radios provide him opportunities for coordinated activity that might otherwise be impossible.

Furthermore, the development of American civilization, a development concomitant with scientific progress, has enhanced the effect of

${ }^{2}$ U.S. ConsT. amend. IV.

${ }^{3}$ Goldman v. United States, 316 U.S. I29, I39. (1942). Interestingly, electronic eavesdropping has occupied the attention of Congress in connection with two very controversial congressional investigations. In one, Senator Joseph McCarthy complained of the transcribing of his conversations with certain Defense Department officials. More recently, the alleged electronic eavesdropping performed by a congressional investigator with respect to Bernard Goldfine, the subject of a sensational influence-peddling investigation, has commanded headlines. In 1957, England's attention was called to wire tapping in connection with proceedings to disbar a British barrister.

'Of course, the automobile has opened up a new category of crimes-traffic offenseswhich are a significant drain on resources. 
criminal activity on society. The most obvious example is espionage, which can change the destiny of nations; but there are many others. Corruption of public officials can be especially injurious in a period when increasing dependence on government has placed new power in the hands of bureaucrats. Other power aggregates, such as labor unions and large corporations, have today such impact on the individual's destiny that perversion of their functions can also undercut democratic ideals. And the development of crime syndicates in the United States to facilitate narcotics traffic, gambling, prostitution, and other crimes is another indication that a complex, industrialized society may face formidable threats from its enemies within.

Accordingly, even though one agrees completely with the premise of Justices Brandeis and Murphy that the courts, in interpreting constitutional restrictions and in supervising criminal law administration, must develop doctrines that will cope with contemporary threats to civil liberties, this doctrinal development should not occur in a vacuum. Instead, it should be accompanied by a recognition that law enforcement agents are now confronted with more formidable adversaries than before, and that success of those adversaries has an ever more ominous import.

As a prelude to examining the manner in which American courts have dealt with new methods of investigation, it may be well to inquire into the rights of the American citizen, with respect to criminal law administration. To a substantial extent, these rights rest on constitutions -federal and state. Especially significant in the Federal Constitution are the fourth amendment, which protects the right of privacy by prohibiting unreasonable search and seizure; the fifth amendment, which precludes compulsory self-incrimination and requires that the individual be granted "due process"; and the fourteenth amendment, which extends to the states the demands of "due process." The state constitutions, for the most part, contain similar requirements that an accused be dealt with according to "due process" and the "law of the land," and without being subjected to unreasonable searches and seizures or to compulsory self-incrimination.

"Due process" is a concept of American law broad enough to embrace the rights which would be deemed fundamental in any civilized society. However, there are instances, to be discussed below, where, with respect to criminal investigative methods, judges have proclaimed that rights existing under "natural law" or "divine law" were also 
infringed. ${ }^{5}$ On other occasions, the development of the rights of a criminal suspect has been through the power of appellate courts to supervise the administration of criminal justice. Thus, the United States Supreme Court, in the exercise of its supervisory power, has held inadmissible any confession that followed a period of unlawful detention without the prompt arraignment required by the Federal Rules of Criminal Procedure, ${ }^{\theta}$ and has ruled that a federal official can be enjoined from testifying in a state court concerning the results of an illegal search conducted by him. ${ }^{7}$ The structure of the American court system has itself been reflected in some of the rights granted accused persons. The allocation of fact-finding to a jury of laymen has played a significant part in the creation of rules excluding evidence that might otherwise be acceptable. For instance, the exclusion of evidence of past criminal acts is predicated, in large part, on the danger that a jury might be distracted from the issue at hand and find a defendant guilty solely because he had criminal tendencies. ${ }^{8}$

In enforcing the rights of the accused, the courts have increasingly excluded illegally-obtained evidence, even, in some instances, the more remote "fruit of the poisonous tree." At the common law, judicial concern was with the trustworthiness of evidence, and not with any illegality in obtaining it, for which the remedy lay in criminal prosecution of the offending law enforcement officer or in a civil suit against him. ${ }^{10}$ With coerced confessions, for example, the misgiving primarily

${ }^{5}$ United States v. Williamson, 4 U.S.C.M.A. 320, 15 C.M.R. 320 (1954) (dissenting opinion of Chief Judge Quinn); McGovern v. Van Riper, 137 N.J. Eq. 24, 43 A.2d 514 (1945). But see subsequent opinion, id., 140 N.J. Eq. 34I, 54 A.2d 469 (1947).

- See, c.g., Mallory v. United States, 354 U.S. 449 (1957); McNabb v. United States, 318 U.S. 332 (1943).

'Rea v. United States, 350 U.S. $2 \times 4$ (1956).

${ }^{8}$ See, e.g., Stone, The Rule of Exclusion of Similar Fact Evidence: America, $5 \mathrm{I}$ HARV. L. REv. 988 (1938); Stone, The Rule of Exclusion of Similar Fact Evidence: England, 46 HARv. L. REv. 954 (1933). See also United States v. Haimson, 5 U.S.C.M.A. 208, 17 C.M.R. 208 (1954). In European courts, the American-type jury system is not used, and, therefore, some of the danger arising from evidence of previous offenses is mitigated.

${ }^{\circ}$ Nardone v. United States, 308 U.S. 338 (1939); Silverthorne Lumber Co. v. United States, 25 T U.S. $3^{85}$ (1920).

${ }^{10}$ See Wolf v. Colorado, 338 U.S. 25 (1949), in connection with the survival of the common law rule as to illegal search and seizure. Some states, however, have swung away from the common-law rule, either by statute, see, e.g., N.C. Gen. STAT. \& I 5-27 (1953), or by judicial decision. See, e.g., People v. Cahan, 44 Cal.2d 434, 282 P.2d 905 (1955). 
was that the accused's involuntary statement would prove untrustworthy; the ethics of coercion were relatively unimportant.11 Today, however, especially under the impact of the United States Supreme Court, a "clean hands" doctrine of law enforcement has come into vogue, under which evidence is often excluded, regardless of its trustworthiness, if the manner of its procurement has infringed certain minimal standards. ${ }^{12}$

In some instances, the remedy of exclusion of illegally-obtained evidence has been required by the Supreme Court in both state and federal criminal proceedings. Thus, the reception in evidence of coerced confessions is a violation of the standards of "due process" applicable to both federal and state courts and will lead to reversal of a conviction in any American tribunal. ${ }^{13}$ On the other hand, each state is free to determine for itself whether it will admit in evidence the products of an unlawful search ${ }^{14}$ or of wire tapping, ${ }^{15}$ at least where a federal investigator is not involved. ${ }^{18}$ As to the treatment of many new investigative techniques, one of the most significant questions today is the extent to which the United States Supreme Court will permit the states to make their own determination concerning the admissibility of the evidence they produce.

\section{II}

\section{Body Fiuids and Substances}

Among the most valuable devices for the investigation of drunken driving cases or the determination of issues of paternity is the bloodtest. ${ }^{17}$ A very reliable index of intoxication or the exoneration of an alleged putative father may result from a competently-administered bloodtest. However, despite, or perhaps because of, its reliability, many a suspect will not voluntarily submit to bloodtesting. To overcome such reluc-

\footnotetext{
${ }^{21} 3$ Wigmore, EVIDENCE $\$ \S 822,856$ (3d ed. 1940).

22 See Rochin v. California, 342 U.S. 165 (1952).

${ }^{23}$ See, e.g., Watts v. Indiana, 338 U.S. 49 (1949); Malinski v. New York, 324 U.S. 401 (1945); Ashcraft v. Tennessee, 322 U.S. 143 (1944). Even courts-martial would apparently be subject to this requirement. See Burns v. Wilson, 346 U.S. 137 (1953).

${ }_{14}$ Wolf v. Colorado, 338 U.S. 25 (1949).

${ }^{25}$ Schwartz v. Texas, 344 U.S. I 99 (1952).

${ }^{20}$ Rea v. United States, 350 U.S. 214 (1956).

${ }^{17}$ Explanation of the medical principles of bloodtesting appears in 7 Buffalo L. Rev. 209 (1958). For excellent legal discussions, see Comment, Constitutional Limitations on the Forcible Extraction of Body Fluids by Law Enforcement Officers, 7 DukE L.J. 25 (1957); Stetler, Medicolegal Aspects of Chemical Tests for Intoxication, I TRIAL LAW. GUIDE 159 (1957).
} 
tance, various alternatives are conceivable: extraction of blood by force; permission to the prosecutor to comment at any trial on the defendant's refusal to be bloodtested; ${ }^{18}$ or revocation of the suspect's driver's license if the blood test were sought in connection with a drunken driving investigation. ${ }^{19}$

Whatever method may be used to compel submission to a bloodtest, three routes of constitutional attack are available: (a) compulsory selfincrimination, (b) unreasonable search and seizure, and (c) deprivation of "due process." As to the first ground, the defendant's most formidable obstacle would be the widespread acceptance of the view that the privilege against self-incrimination concerns "testimonial utterances"occasions where the suspect is indicating his own belief or disbelief in some proposition and where his credibility is involved. ${ }^{20}$ Aside from the questionable trustworthiness of what he may say, the suspect is not compelled to make the moral choice whether to lie in his own behalf, or instead to tell the truth and take the consequences. Many continental countries apply a similar concept, for, although he may be interrogated by the judge, the defendant is not placed under oath and is not subjected to the moral choice of jeopardizing his safety on the one hand, or of violating the moral obligation of the oath and risking perjury prosecution on the other. ${ }^{21}$ However, where a bloodtest is involved, there is no such moral choice to be made by the suspect and no opportunity for

\footnotetext{
${ }^{28}$ See Adamson v. California, 332 U.S. 46 (1947), as to comment on a defendant's silence. But cf. Grunewald v. United States, 353 U.S. 391 (1957).

${ }^{20}$ Actually, revocation of operator's license is in many states one of the most dreaded consequences of a conviction of drunken driving, but in a manslaughter investigation, it would have less import. The theory for revocation of license would be that of Hess v. Pawloski, 274 U.S. 352 (I927).

${ }^{20}$ See, e.g., 3 WIGMORE, op. cit. supra note $\mathrm{II}, \S 2265$, and cases cited therein. See also Holt v. United States, 218 U.S. 245 (19xo). This is somewhat similar to the hearsay concept.

${ }^{31}$ In American law, the defendant is put under oath and is subject to prosecution for perjury. One interesting question that has received judicial attention is the extent to which a perjury prosecution is barred by the defendant's acquittal or conviction. United States v. Williams, 34I U.S. 58 (I95I); State v. Leonard, 236 N.C. 126, 72 S.E.2d I (1952). See also, Comment, Acquittals or Convictions as Bars to Prosecutions for Perjury, x DUKE B.J. xox (195x). Under the European system, it is always possible that a lying defendant may receive a heavier sentence, in the exercise of judicial discretion, than if he had told the truth. The silent defendant, on the other hand, may afford some basis from which the court may draw an adverse inference. For an interesting general discussion of European criminal procedure as compared with American, see Schwenk, Comparative Study of the Law of Criminal Procedure in NATO Countries under the NATO Status of Forces Agreement, 35 N.C. L. REv. $35^{8}$ ( $(957)$.
} 
suppression or revelation of the truth, since the reliability of the test is completely independent of the person tested.

As to the objection of unreasonable search and seizure, in some jurisdictions, the answer would be readily apparent: The unreasonableness of a search and seizure does not affect admissibility of evidence obtained thereby. ${ }^{22}$ In the federal courts, on the other hand, an illegal search does result in inadmissibility; and, generally speaking, authority does not exist, even under a search warrant, to search for "mere evidence" of crime, as distinguished from the "instruments" or "fruit" of a crime. ${ }^{23}$ Conceivably, in drunken driving, the driver's alcoholladen blood might be deemed an "instrument" of the crime, but this seems a strained construction. Another approach might be to deny that the extraction of blood constituted either a "search" or a "seizure" within the meaning of the fourth amendment; certainly, this investigative technique was not known in the eighteenth century. And the California Supreme Court recently overcame the unreasonable-search objection in still another way. Pointing to the rule that, "where there are valid grounds for an arrest, a reasonable search of a person and the area under his control to obtain evidence is justified as incident to arrest," the court ruled bloodtesting to be legal if incident to a valid arrest. ${ }^{24}$ This approach causes the validity of the bloodtesting to hinge on legality of the arrest; but in many instances, no hindrance to investigators would be occasioned thereby.

The "due process" objection to extraction of a blood specimen depends particularly on the United States Supreme Court's decision in Rochin v. California. ${ }^{25}$ There, the stomach-pumping of a narcotics suspect who, when apprehended, had swallowed the drug, was deemed to be "conduct that shocks the conscience" and thus a violation of "due process." The Court emphasized that the trustworthiness of the evidence obtained from Rochin's stomach did not vitiate the "due process"

\footnotetext{
${ }^{22}$ See Wolf v. Colorado, $33^{8}$ U.S. 25 (1949); People v. Duroncelay, 48 Cal.2d 766, 312 P.2d 690 (1957).

${ }^{23} C f$. Marron v. United States, 275 U.S. 192 (1927). For an unusual case, sec United States v. DeLeo, 5 U.S.C.M.A. 148, 17 C.M.R. 148 (1954).

${ }^{24}$ People v. Duroncelay, 48 Cal.2d 766, 312 P.2d 690, 693 (1957). The court considered it to be unimportant that the search precedes the arrest where there are reasonable grouuds for arrest. In People v. Haeussler, 4I Cal.2d 252, 260 P.2d 8 (1953), blood-extraction had been ruled legal, but at that time in California, unreasonable search and seizure did not impair admissibility.

${ }^{25} 342$ U.S. 165 (1952).
} 
objection, just as an involuntary confession remains inadmissible even if independently corroborated.

In a later case, however, Breithaupt v. Abram, the Court determined that bloodtesting is a far cry from stomach-pumping. ${ }^{26}$ One Breithaupt had been involved in an automobile accident in New Mexico, after which, while he lay unconscious in a hospital emergency room, a sample of about twenty cubic centimeters of blood was withdrawn by an attending physician by use of a hypodermic needle. On the basis of subsequent laboratory analysis of this sample, an expert witness testified that Breithaupt was intoxicated at the time of the collision; and this, in turn, led to a manslaughter conviction. In rejecting the argument that a deprivation of "due process" had occurred, Justice Clark commented for the majority: ${ }^{27}$

There is nothing "brutal" or "offensive" in the taking of a sample of blood when done, as in this case, under the protective eye of a physician. ... The blood test procedure has become routine in our everyday life. It is a ritual for those going into the military service as well as those applying for marriage licenses. Many colleges require such tests before permitting entrance and literally millions of us have voluntarily gone through the same, though a longer, routine in becoming blood donors. Likewise, we note that a majority of our States have either enacted statutes in some form authorizing tests of this nature or permit findings so obtained to be admitted in evidence.

After remarking on the traffic hazard created by drunken drivers, Justice Clark concluded that the injury to the individual which results from the performance of a properly safeguarded bloodtest-today so routine in our society-is far outweighed in significance by the need to use the blood test in detecting traffic offenders.

The opinion's emphasis on performance of the blood test under medical safeguards clearly suggests that not every policeman will be allowed to draw blood at his whim. However, unless the blood is extracted by a technically qualified person, the admissibility of testimony based on the blood sample could be seriously questioned on grounds of unreliability, apart from "due process" concepts. The majority does not rule on whether a blood sample extracted by federal investigators would

\footnotetext{
${ }^{20} 352$ U.S. 432 (1957).

${ }^{27} 1 d$. at $436-438$. The opinion cites the various state statu+as and decisions relevant to bloodtesting.
} 
be admissible; but for crimes within federal jurisdiction, the blood test will generally not be a valuable investigative adjunct. ${ }^{28}$

In so far as Justice Clark's rationale is concerned, some may voice the criticism that to recite the widespread use of blood tests does not prove that they conform with "due process" when used by criminal investigators. Yet, the familiarity of the general public with blood tests does indicate that they should have no traumatic effect on a suspect when administered by a physician; in other words, the chance of psychological discomfort appears slight. Furthermore, their routine and extensive use attests to the safety of blood tests and prevents the attachment of any stigma to the person whose blood is tested in a criminal investigation. ${ }^{29}$ Protection of the contents of the human body against inspection by investigators is of vital importance when such invasion produces significant pain, risk of infection, or physical injury, ${ }^{30}$ psychological shock, or a feeling of humiliation. To go further than this and prohibit the unconsented extraction of any evidence that comes from within a suspect's body, however, unduly minimizes society's needs. ${ }^{32}$

American military jurisprudence also has had occasion in recent months to consider the legality of the bloodtest. ${ }^{32}$ In United States $v$. Musguire, ${ }^{33}$ the Court of Military Appeals considered whether a serviceman could be prosecuted for disobedience of an order to submit to a bloodtest. Article thirty-one of the Uniform Code of Military Justice ${ }^{34}$ provides: "No person subject to this chapter may compel any person to incriminate himself or to answer any question the answer to

${ }^{29}$ However, in determining claims of citizenship, blood tests might be valuable. The legality of their use for such a purpose is now being determined. See Lee Kum Hoy v. Murff, 355 U.S. 169 (1957).

${ }^{20}$ The presence or absence of a stigma in connection with an investigative technique is discussed below with respect to fingerprinting. In connection with bloodtesting, it would seem that evidence obtained thereby should also be useful and admissible for subsequent civil litigation in instances where a collision has occurred. But see, Hamilton v. Becker, 86 N.W.2d 142 (Iowa 1957); Note, 44 Iowa L. REv. 210 (1958).

${ }^{30}$ With the stomach-pumping involved in Rochin v. California, 342 U.S. 165 (1952), there would seem to exist a likelihood of considerably greater physical discomfort than in extracting a blood sample.

${ }^{31}$ It might be argued that if punishments can accomplish a purging of guilt feelings and an improvement of the criminal's attitudes toward society, then he will himself profit in the long run from being detected and even his individual interests will be benefited by his compulsory exposure to accurate investigative procedures of whatever kind.

${ }^{32}$ Military jurisprudence has produced some very interesting decisions as to criminal investigations. See EveretT, Military JUstice c. V (1956).

${ }^{33} 9$ U.S.C.M.A. 67,25 C.M.R. 329 (1958).

${ }^{34}$ 1o U.S.C. $\$ 8$ 1 $(1956)$. 
which may tend to incriminate him." It also requires a warning to any suspect who is to be interrogated or from whom a statement is to be requested that he is entitled to remain silent and that any statement made by him may be used as evidence against him in a trial by courtmartial. To the court it seemed that an order to submit to a bloodtest involves compelling the recipient to "incriminate" himself, and so is illegal.5 Noting that Breithaupt v. Abram had not decided the admissibility in federal courts of evidence obtained by a bloodtest without the accused's consent, the Court of Military Appeals declined to consider whether such evidence should be received in courts-martial. ${ }^{36}$ But if an order to submit to bloodtesting is illegal, is it permissible for the military investigator to draw a blood sample by force? In light of the structure and traditions of the armed services, it would seem somewhat incongruous to say that a superior officer may take blood from a subordinate by force but that he cannot order submission to the bloodtest. And a question arises as to what criminal liability will attach to the subordinate if he resists with force the proposed bloodtest?

The Court of Military Appeals has also been called upon to discuss the use of another type of body fluid in criminal investigation. The presence of large American military contingents in the Orient, where narcotics are relatively accessible, has created a serious problem for the armed forces. Since there are several well-recognized tests for determining the presence of a drug through analysis of a suspect's urine specimens, military investigators have often sought to obtain such specimens. Frequently, the suspect has complied willingly with the investigator's requests. On other occasions he has not been so cooperative, whereupon the investigator has sometimes had him catheterized. This process involves insertion of a catheter, a rubber tube, through the urethra, into the urinary bladder, and the consequent involuntary extraction of urine, which can then be subjected to laboratory tests.

\footnotetext{
${ }^{25}$ The court also noted that to be lawful, an order must relate to "military duty," and there is no military duty to produce evidence against oneself. See United States v. Aronson, 8 U.S.C.M.A. 525, 25 C.M.R. 29 (1957).

${ }^{86}$ If an accused cannot be compelled to give blood, must he be specifically warned of bis right to refuse to submit to blood extraction, just as he must be told that he does not have to give a "statement"? The answer seems uncertain. See United States v. Musguire, supra note 33; United States v. Minnifield, g U.S.C.M.A. 373, 26 C.M.R. 153 (1958); United States v. Jordan, 7 U.S.C.M.A. 452, 22 C.M.R. 242 (1957); United States v. Barnaby, 5 U.S.C.M.A. 63, 17 C.M.R. 63 (1954). In a very recent case, it was decided that the $i$ esult of a bloodtest taken pursuant to a drunk-driving statute was admissable in a subsequent prosecution for drunken driving. Kay v. United States, 255 F.2d 476 (4th Cir. 1958).
} 
In United States $v$. Williamson ${ }^{37}$ the evidence revealed that the accused was discovered in a coma in the house of a Japanese national and was rushed by military ambulance to a hospital, where he was, examined by an American medical officer. While Williamson was still unconscious, a specimen of urine was extracted from his bladder with a catheter, and analysis of the specimen disclosed the presence of morphine. Judges Latimer and Brosman considered the evidence to be admissible, although the latter did not consider that involuntary catheterization of a conscious suspect would be permissible in light of the psychological impact potential possessed by this type of scientific exploration.

Chief Judge Quinn began his forceful dissent by noting that in his opinion, a serviceman "is entitled not only to the benefits of the Uniform Code of Military Justice, but to the safeguards of the Bill of Rights of the Constitution of the United States as well, and, as a human being, is also entitled to the protections of both natural and divine law."38 After an analysis of relevant cases, with special attention to Rochin $v$. California, the Chief Judge returned to the theme of divine and natural law, as expounded from the days of Plato and Cicero, and concluded with the observation that "these inalienable rights, which are implicit in the Law of Nature, and of Nature's God, demand that the sanctity of the human body, made in the image and likeness of God-the temple of his immortal soul-be and remain forever sacred and inviolate."130 It seems fair to say that Judge Quinn's invocation of both natural and divine law is almost unique in recent American court opinions!

Subsequently, the Court of Military Appeals ruled that an accused could not be forced to submit to catheterization, ${ }^{40}$ but that no warning of this fact need be given to a suspect, despite the usual requirement in military law that a suspect be warned of his right to decline to make any "statement."41 Apparently, too, a majority of the court originally considered that an accused could by a military order be compelled to furnish a urine specimen to the investigator. ${ }^{42}$

Apparently owing to a change of court membership as a result of

${ }^{37} 4$ U.S.C.M.A. 320, 15 C.M.R. 320 (1954).

${ }^{38} 4$ U.S.C.M.A. at 331 , 15 C.M.R. at 331 .

${ }^{30} 4$ U.S.C.M.A. at 335,15 C.M.R. at 335 .

${ }^{10}$ United States v. Jones, 5 U.S.C.M.A. 537, 18 C.M.R. 161 (r955).

${ }^{4}$ United States v. Booker, 4 U.S.C.M.A. 335, 15 C.M.R. 335 (1954).

${ }^{42}$ See United States v. Williamson, 4 U.S.C.M.A. 320, 15 C.M.R. 320 (1954); United States v. Barnaby, 5 U.S.C.M.A. 63 , 17 C.M.R. 63 (1954). 
one judge's death, ${ }^{43}$ the use of orders to obtain a urine specimen was later repudiated when the question was squarely presented in United States v. Jordan.44 An Airman Jordan had been ordered that "the next time he urinated he was to give the OSI a specimen of his urine." A majority of the Court considered that this order was illegal and that it entrenched upon the privilege against self-incrimination guaranteed by article thirty-one of the Uniform Code of Military Justice. Yet, only the Chief Judge was willing to say explicitly that any evidence obtained by virtue of such an illegal order would be inadmissible in a court-martial.

Although compulsory catheterization would seem to involve excessive invasion of the human body, the protection granted to an accused by the Jordan decision gives too little weight to the interests of the public in the detection of narcotics offenders. Actually, no invasion of Jordan's person was threatened, and there was no prospect of pain to him. A majority of the Court was apparently adopting an interpretation of selfincrimination which would tie the hands of the investigator. Whether such an interpretation is demanded by the wording of article thirty-one of the Uniform Code is highly doubtful; ${ }^{45}$ but perhaps other courts will disregard the decision as being interwoven with the peculiarities of military justice.

In two other federal decisions, urine specimens were held admissible despite claims that they had been furnished under coercion. In Bratcher v. United States, ${ }^{46}$ the specimen had been obtained as part of a physical examination preliminary to induction for military duty, and chemical analysis revealed that the defendant had been taking benzedrine, a drug which would tend to increase his blood pressure and thereby disqualify him for military duty. In a prosecution for violation of the Selective Training and Service Act, the Court of Appeals summarily rejected the contention that Bratcher had been subjected to an unreasonable search and seizure or to compulsory self-incrimination. Since the court specifically noted that the evidence was obtained solely in the course of

\footnotetext{
${ }^{43}$ Judge Brosman died in December, 1955, and was replaced by Judge Homer Ferguson.

4t 7 U.S.C.M.A. 452, 22 C.M.R. 242 (1957) ; 25 GEo. WASH. L. REv. 734 (1957).

"It seems to be agreed that the word "iucriminate" in article 3 I embraces only the concept of self-incrimination implicit in the fifth ameudment.

${ }_{\text {40 }}^{449}$ F.2d 742 (4th Cir. 1945), cert. denied, 325 U.S. 885 (1945).
} 
learning if the defendant was acceptable for military service, the opinion does not clearly support the proposition that it would be proper for criminal investigators to obtain a urine specimen from a suspect without his consent. ${ }^{47}$

In United States $v$. Nesmith, ${ }^{48}$ the prosecution was for manslaughter. After an automobile accident, the defendant had been "requested" or "directed" by a law enforcement officer to furnish a urine specimen to determine therefrom whether he had been driving while intoxicated. Defendant complied with the direction, but at his trial, he moved to suppress the specimen on grounds of a violation of his privilege against self-incrimination. District Judge Holtzoff, in light of the Supreme Court's opinion in Holt $v$. United States, ${ }^{49}$ where the privilege against self-incrimination had been limited to testimonial utterances, held that the urine specimen-not itself being testimony-did not fall within the scope of the constitutional protection. Whether a deprivation of due process would be involved if force or threats had been used against Nesmith, or if he had been subjected to catheterization, was specifically left undecided. Subsequently, in interpreting this Holtzoff opinion in the Jordan case, Chief Judge Quinn of the Court of Military Appeals appears to have mixed the "due process" issue-which was left undecided in Nesmith-with the question of the applicability of self-incrimination to urine specimens, as to which a clear and negative answer was returned. ${ }^{50}$

${ }^{47}$ In some instances, the privilege against self-incrimination is limited in operation when evidence is sought for reasons other than incrimination of the person requested for information. Cf. Shapiro v. United States, 335 U.S. × (1948).

${ }^{48}$ 121 F. Supp. 758 (D.D.C. 1954).

${ }^{10} 2 \times 8$ U.S. 245 (1910).

${ }^{50} 7$ U.S.C.M.A. at 455,22 C.M.R. at 245 . As to urinalysis, one other case deserves mention.- In State v. Gatton, 6o Ohio App. 192, 20 N.E.2d 265 (1938), it was held that no error was committed in a drunken driving case in allowiug proof that the defendant had refused to submit to bloodtests or urinalysis and in permitting the prosecution to comment on this reticence. According to the court, self-incrimination was not involved, and the defendant should not be given the benefit of what this tribunal deemed sentimentality. It deserves mention, though, that in one sense, selfimcrimination is involved more in evidence of refusal to be scientifically tested than in evidence as to results of a test. In the former instance, the inference is invited that the defendant implicitly admits his own guilt by declining to permit scientific ascertainment of the facts. Thus, the court is considering the accused's opinion of his own guilt, and he becomes a witness against himself. On the other hand, where a blood or urine sample is obtained, the accused's opinion of his own guilt is almost immaterial; the opinion of the expert is the critical thing. 


\section{Fingerprints and Photographs}

Any book about the Federal Bureau of Investigation will refer to its extensive fingerprint files, in which the fingerprints of some $70,000,000$ persons are reputed to be recorded. ${ }^{51}$ As part of the same emphasis on detection and identification of criminals, numerous state statutes provide for fingerprinting under certain circumstances. Moreover, until recently fingerprinting was required of aliens who were entering the United States on other than an official visa. ${ }^{52}$

In many foreign lands, fingerprinting and the retention of prints in police files are much less common. Indeed, in some lands, only the fingerprints of convicted offenders-usually serious offenders-are retained by the police. Thus, fingerprinting there becomes, to some extent, a badge of infamy. On the other hand, in the United States it is routine in many contexts: persons entering the armed forces and applicants for passports and many types of licenses-including, in some jurisdictions, law licenses-must be fingerprinted. ${ }^{53}$ In some hospitals, new-born babes are fingerprinted routinely. ${ }^{54}$ Moreover, at the urging of investigative authorities, many persons have voluntarily been fingerprinted for identification purposes in the event of amnesia, accident, or other catastrophe; and it has been proposed by a few persons that fingerprinting should be made compulsory for all American citizens.

Against this background, it might have been foreseen that attacks on involuntary fingerprinting of suspects and arrested persons would be, for the most part, unsuccessful. The most recent case involved a suit by one Roesch, who sought the return of his fingerprints and photographs for the purpose of destruction. The plaintiff, a prelaw college student, had been arrested in New Jersey for a speeding violation and was committed before trial to the county jail, where, despite his objection, he was fingerprinted and photographed by the police. Ultimately, Roesch had pleaded guilty in the criminal case and paid a small fine.

In weighing the contention that the plaintiff had been improperly embarrassed and that his privacy had been invaded, the Appellate

52 WhItEhEAd, THE FBI STORX 139 (1956). This figure includes both civil and criminal identification files. On the other hand, Scotland Yard retains only the prints of criminals. See HarRison, THE C.I.D. AND THE F.B.I. 45 (1956).

${ }^{62} 7 \mathrm{r}$ STAT. 641, 8 U.S.C. § I201a (1957).

${ }^{83}$ See Roesch v. Ferber, 48 N.J. Super. 23I, I37 A.2d 6I (App. Div. 1957); State ex rel. Mavity v. Tyndall, 224 Ind. 364,66 N.E.2d 755 (1946).

st 1bid. 
Division of the New Jersey Superior Court inquired whether at common law a person under arrest could be fingerprinted. Thomas Hobbes's theory of social compact, and the writings of John Locke and Blackstone were all cited for the proposition that the requirement of fingerprinting and photographing is a necessary subjection of the individual to the needs of society. The court concluded that as to fingerprints or photographs of a person charged with crime, the retention of the records remains within the discretion of the police. It was added: ${ }^{55}$

We have seen that courts recognize that situations may possibly arise where equitable relief such as that sought here may be warranted. However, the equities must be strongly in favor of the complainant for this court to interfere with the valid administrative procedures of our law enforcement agencies. We now reaffirm that where no statute prohibits the taking or governs the return of identification records, the retention or return of such records lies solely within the sound discretion of the police authorities.

Since Roesch had been convicted of the offense charged, his claim for judicial relief was weak, the court remarking that no case, either in New Jersey or elsewhere, had even considered the return of fingerprints and photographs where the person involved was convicted of the charge. Also, in so far as the plaintiff's case was based on humiliation in having his fingerprints in police files, he was confronted with the court's view that the continually expanding use of fingerprints has dispelled the alleged stigma formerly associated with police identification measures.

As with the bloodtest, the reply can be made that Roesch should not have been subjected to the "humiliation" of having his fingerprints and photograph in the hands of the New Jersey police and the Federal Bureau of Investigation simply because many people who are not criminals have been fingerprinted. However, in so far as protection of the individual from embarrassment is concerned, the attitude of the community would appear all important. For instance, whether certain language is truly defamatory may often depend on the attitude of the

${ }^{55}$ Roesch v. Ferber, 48 N.J. Super, 231, 一, 137. A.2d 61, 72 (App. Div. 1957); 106 U. PA. L. REV. 303 (1957). For some reason, New Jersey has been the situs of considerable fingerprint litigation. 
community towards the particular words. ${ }^{56}$ In a sense, the "right" to use such language depends to some extent on the feelings of the community..$^{57}$ As to fingerprinting, a strange interpenetration exists between law and custom. The Federal Bureau of Investigation and other law enforcement agencies have induced a large-scale acceptance of fingerprinting as a routine method of identification in both civil and criminal matters. This acceptance, in turn, now limits the right of an arrested person to resist fingerprinting, since he is not being "humiliated" thereby-at least, in so far as his relation to others is concerned.

What, though, of the right to privacy-really, in this context, the right to keep police in ignorance of one's identity and criminal record, if any? The possibility always exists that a perfectly innocent man will be the subject of undue police suspicion, because investigators learn of his previous record-even though he may only have been arrested and never convicted. Conceivably, efforts will be made to "build a case" against him because of this record. On the other hand, a man's pastthough his record shows no convictions-can be of great value to the investigator. For instance, if a suspect is arrested on a narcotics charge, it will be of logical importance to the investigator that the fingerprint files show he was arrested twice before on similar charges. The absence of previous convictions after arrest will not be all-important-at least, so long as it is recognized that some guilty persons are acquitted along with the innocent.

Apart from information as to a suspect's past criminal record, the police find their fingerprint and photograph files of immense value in detecting criminals. And, in turn, the increased likelihood of detection may deter some persons from projected crimes. If the right of privacy were deemed to demand deletion from police files of the fingerprint records of persons who had been arrested and later acquitted or never tried, then this same right would seem to require deletion from court or police records of all arrests that did not eventuate in conviction. Yet, such does not seem to be the practice, even though the court records are usually much more open to the public than are police fingerprint files. Also, under an all-encompassing interpretation of the right of privacy,

\footnotetext{
${ }^{8 B}$ In the United States, it might be defamatory to call one a Communist; but certainly not so in Moscow.

${ }^{87}$ There is no need to quibble in this connection over the meaning of a legal "right." The point is that while one must so conduct himself as not to damage others, a variety of circumstances will determine what constitutes damage. In so far as alleged harm is concerned, one of the most significant circumstances may be the attitude of the community.
} 
newspaper practices concerning the reporting of arrests would require drastic overhauling. Certainly there seems no reason to single out police fingerprint and photograph files for special treatment simply because they provide the most speedy and most accurate method of ascertaining a suspect's past record. And, of course, sometimes swift exoneration instead of incrimination can come from a fingerprint check.

In practice, the alleged right of privacy in so far as police compilation of fingerprint files is concerned often boils down to a right to falsify safely. The applicant for certain types of jobs, especially with the government or in defense industry, the enlistee in the armed services, the person seeking a driver's license or a permit to sell alcoholic beverages-these and many others will be asked questions about their past. The fingerprints which are often taken on such occasions have frequently either deterred falsehood or have detected it. Perhaps too many activities in America are today surrounded by overly-stringent requirements; for example, some would say this with respect to government employment. However, the remedy does not rest in curtailing the enforcement of such requirements by the placing of limitations on police çompilation of fingerprint files. The chief result of any such limitations will be merely to increase the temptation to falsify applications for government jobs, drivers' licenses, and the like-a result which promises little benefit either to society or to the individual who is tempted.

One New Jersey jurist, however, made clear in the case of $M c$ Govern $v$. Van Riper, ${ }^{58}$ that he did not consider the alleged right of privacy in one's fingerprints and photographs to be outweighed by society's need to arm the police with advanced detection techniques. McGovern, the Sheriff of Hudson County, New Jersey, was himself under indictment for having failed to cause certain persons to be photographed pursuant to State law. He sought an injunction against the taking of his own fingerprint and photograph and the dissemination of copies to other police agencies, such as the Federal Bureau of Investigation. In light of an individual's right to privacy and protection against humiliation, Vice Chancellor Kays ruled that ${ }^{58}$

there is no justification for the taking of fingerprints, photographs and other measurements in advance of conviction except where the sole purpose to be served is to identify the accused as the person charged with the offense for which he is taken into

\footnotetext{
${ }^{58}{ }_{137}$ N.J. Eq. 24, 43 A.2d 514 (1945); 137 N.J. Eq. 548, 45 A.2d 842 (1946).

${ }^{80}$ Id. at 44,43 A.2d at 524 .
} 
custody, or for the purpose of using them to facilitate the recapture of an accused who becomes a fugitive.

Therefore, dissemination of fingerprints and photographs for criminal identification purposes before conviction would be improper, unless an accused should become a fugitive; and a statute requiring such dissemination would be held unconstitutional. The Vice Chancellor emphasized that the right of privacy which he was seeking to protect had its "origin in the law of ancient Rome and Greece" and "having its origin in natural law, is immutable and absolute, and transcends the power of any authority to change or abolish it. . . . It is one of the 'natural and inalienable rights' recognized in Art. I, par. I of the Constitution of this State. ${ }^{\text {"30 }}$

This opinion was repudiated by a later decision in the same case; and another Vice Chancellor ruled that the fingerprints and photographs of Sheriff McGovern could be disseminated, even though two years had elapsed without trial on the indictment against him, the right of privacy being deemed subject to limitation by the rights of the public: ${ }^{\text {aI }}$

Acceptance of restrictions upon the so-called natural rights of every individual necessary to ensure observance by the individual citizens of the duty to use his property and exercise his rights and privileges with due regard to the personal and property rights and privileges of others, is the first and most imperative obligation entering into what we call the social compact.

Obviously, if fingerprints and photographs are not to be disseminated to other law enforcement agencies until after the suspect has been convicted, investigators are materially hampered. For instance, they may be unable to learn of previous convictions, which might be admissible in impeaching the accused if he testifies at a trial or puts his character in issue, and which, if he is convicted, might bear on an appropriate sentence, under both habitual offender laws and otherwise. In some instances, too, information of other offenses may provide substantive evidence of guilt by showing plan, intent, motive, or the like. ${ }^{62}$ The added privacy given an accused by retaining his prints and photograph in the hands of the police who have apprehended him, instead of per-

\footnotetext{
${ }^{\circ 0}$ Id. at 33,43 A.2d at 5 ig.

ox McGovern v. Van Riper, 140 N.J. Eg. 341, 345, 54 A.2d 469, 471 (1947), quoting Pine v. Okzewki, II 2 N.J.L. 429, 438, I70 Atl. 825, 830 (1934).

O2 2 Wigmore, EVIDENCE $\$ \S$ 300-73 (3d ed. 1940).
} 
mitting dissemination to other law enforcement groups, does not seem to counterbalance the resulting hindrance to the police. Indeed, to some extent, fingerprinting would be robbed of value if more courts took the view of those that have enjoined dissemination of fingerprint information. ${ }^{63}$

There is an obvious relationship between the dissemination of information, and its return to the accused for destruction in the event of acquittal. Once copies of prints and photographs have been delivered by local police to the Federal Bureau of Investigation, their return or destruction cannot directly be compelled by a state court. At one time, as a matter of practice, the Federal Bureau of Investigation would destroy or surrender fingerprints or photographs if a suspect was acquitted or discharged without trial ${ }^{64}$ but no such practice is required of the Bureau by any federal statute.

The following picture of state legislation as to fingerprinting is given by a recent law review comment: ${ }^{65}$

Some of these statutes allow any prisoner to be fingerprinted no matter what the charge against him, while others specifically forbid the fingerprinting and photographing of persons arrested for minor violations. The inajority of jurisdictions, however, make it the duty of police officers to take identification data in certain situations, such as when the prisoner is suspected of felony, while either affirming nor denying [sic] their authority to act under other circumstances. Some states have placed statutory restrictions upon the use of these records. These restrictions may provide for the return of the prisoner's fingerprints, photographs and other data upon his acquittal or, if no action is brought, upon his release. In addition, a number of jurisdictions have limited the use of this data to law enforcement officers.

${ }^{63}$ In Hansson v. Harris, 252 S.W.2d 600 (Tex. Civ. App. 1952), the court refused to enjoin transmission of prints and photographs to other law enforcement agencies. Apparently, Texas does not recognize the right of privacy. For some older cases taking the opposite position, however, see Itzkovitch v. Whitaker, $\times 15 \mathrm{La} .479$, 39 So. 499 (1905), and State ex rel. Reed v. Harris, 348 Mo. 426, 153 S.W.2d 834 (1941). See also Poyer v. Boustead, 3 Ill. App.2d 562, 122 N.E.2d 838 (I954).

o See United States v. Kelly, 55 F.2d 67, 70 (2d Cir. 1932). For other federal cases on fingerprinting, see United States v. Iacullo, 226 F.2d 788 (7th Cir. 1955); United States v. Amorosa, 167 F.2d 596 (3d Cir. x 948 ).

os 106 P. PA. L. Rev. 303, 304 (1957). See also Note, 27 TEmple L.Q. 44 (1954). Noncompliance with statutory restrictions may lead to a civil suit against the police officers. North Carolina differentiates fingerprints from photographs. N.C. GeN. STAT. § $148-79$ (1953). 
In addition to express statutory restrictions on fingerprinting, a New Jersey case considers the state's juvenile laws a bar to fingerprinting of a juvenile. ${ }^{66}$

An Indiana case, State ex rel. Mavity v. Tyndall67 displays a sound exercise of judicial discretion as to treatment of fingerprints and photographs. Mavity was arrested for gaming and, thereafter, against his will, was fingerprinted and was photographed with a card, on which there were certain numbers, placed across his chest. His signature was taken and a personal description added. The local police sent copies to state authorities and to the Federal Bureau of Investigation. After the charges against him were dismissed, Mavity sought the return of the data on file with the various police agencies. $\mathrm{He}$ alleged that his picture would be put in a "rogues' gallery" and that this would injure his reputation and cause him humiliation and mental suffering. The Indiana Supreme Court concluded that the actual taking of fingerprints under ordinary circumstances is not an indignity. Moreover, in light of the manner in which fingerprints are filed and indexed, they are available and valuable only to the expert searching for criminals and tell nothing to the idle curious whose gossip might hurt one's reputation. On the other hand, to display publicly in a "rogues' gallery" the photograph of an innocent man would constitute an undue invasion of personal rights. The Court noted: ${ }^{68}$

Whether names, or merely numbers, appear on the photographs is not alleged. At least his bears a number. And this is not a pleasant thought for one conscious of his complete innocence of crime. Is the placing of appellant's picture in the "rogues' gallery" described in the complaint so serious a violation of appellant's right of privacy as to justify judicial protection? Most of the cases so hold and we are constrained to follow them.

Thus, the Supreme Court of Indiana was willing to grant relief against any exhibition of Mavity's photograph which, because of the number thereon and of other circumstances, might induce the false belief that he had been convicted of crime. Further than this the court declined to go. Accordingly, when on a second appeal, it appeared that

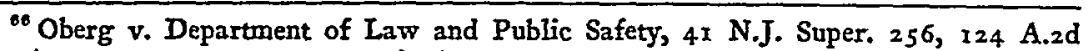
618 (Juv. and Dom.Rel.Ct. I956) (14-year old who had been defendant in juvenile court).

${ }^{77} 24$ Ind. 364,66 N.E.2d 755 (1946).

${ }^{88} I d$. at 381,66 N.E.2d at 762 .
} 
the plaintiff had deleted from his complaint any allegation of an intent to display his picture and photograph in a "rogues' gallery," the court ruled that he was not entitled to any relief under either Indiana law or the Federal Constitution. ${ }^{69}$

Many persons, and especially those from foreign lands where fingerprinting is reserved for serious offenders, would agree with the view of Vice Chancellor Kays that the collection and dissemination of fingerprints, photographs, and similar information seem to be almost an obsession among modern American law enforcement agencies. However, in light of the mobility of the people, the large areas involved, and the existence of many separate political units, it seems that American law enforcement agencies have more need for extensive fingerprint information than might the police in some countries. Moreover, the American visitor to foreign lands will often discover forms of police surveillance that are in some ways more onerous than fingerprinting. For instance, in some European countries the alien who checks into a hotel may have to fill out a detailed police form and exhibit his passport for inspection by the hotel officials.

As a practical matter, the widespread use of fingerprinting that has already been accoinplished makes it unnecessary to consider enactment of statutes that would require all persons in the United States be fingerprinted. Indeed, any such prograin would present administrative difficulties not cominensurate with the value of new information to be gained thereby. However, the objections to universal compulsory fingerprinting seem to have been overstated. While such information would admittedly be of aid to the police in catching criminals, this does not mean that this country would become a "police state." The investigative efficiency of the police is not an index of their desire to limit civil liberties; indeed, the availability of advanced investigative techniques will often limit the temptation for policemen to use methods such as the "third degree," which really injure civil liberties.

Some would argue that anyone who is fingerprinted thereafter is regarded by the police as a potential criminal, and, therefore, if all citizens were fingerprinted, all would be regarded by the police as potential criminals, with a consequent hostility of police to the public. Do the police regard all servicemen today as potential criminals, since all servicemen are fingerprinted? Indeed, if all persons-including law agents themselves - were required to be fingerprinted, it seems

\footnotetext{
${ }^{\circ 0} 225$ Ind. 360,74 N.E.2d 914 (1947), appeal dismissed, 333 U.S. 834 (1948).
} 
clear that no stigma would attach to a fingerprinted person in the minds of the police or of anyone else. It is suggested, therefore, that although today it would be almost superfluous, compulsory fingerprinting would be as justifiable legally as, for example, compulsory smallpox vaccination.

No one can deny, of course, that fingerprint and photograph files, like any other police files, are subject to misuse. To some extent, blackmail and extortion statutes provide a safeguard; but there are situations involving an attempt to damage someone's reputation where such laws would be unavailing. Probably both federal and state legislation would be desirable to assure that information obtained from the fingerprint files of the FBI and other agencies will not be released to persons who have no legitimate need therefor, and to provide a penalty for improper release of such information.

Of course, in drafting such legislation, there would still be some questions as to who had a legitimate need for such information. For instance, what about an attorney who wished to know about any criminal record of certain prospective witnesses so that he would have a basis for impeachment, if necessary? Should he be allowed such information, or should he be entitled to it as a matter of right? Or what about an employer who wishes information about the record of a prospective employee? Should he be. entitled to information derived from fingerprint files maintained by the FBI and by other police agencies-particularly if he obtains an authorization from the prospective employee? Perhaps some sort of judicial proceeding would be appropriate in passing on requests for information based on police fingerprint files-particularly those of the FBI.

\section{IV}

\section{Handwriting Samples}

In prosecutions for forgery and similar crimes, the testimony of the handwriting expert may be all-important. For him to link the defendant with the crime charged requires that he have some samples of defendant's handwriting. This occasionally may present difficulty since, as noted above, an investigator is not allowed to search for and seize mere "evidence" as opposed to the "instruments" or "fruit" of crimeand only in the rare case will a handwriting sample rise above the level of "evidence."

${ }^{30}$ But see United States v. DeLeo, 5 U.S.C.M.A. 148, 17 C.M.R. I48 (1954), for the rare case where handwriting samples were considered to. be "instruments" for a forgery. 
Since one premise of handwriting testimony is that the characteristics of one's handwriting are in part involuntary, ingrained in habit, and incapable of complete disguise, some investigators simply ask the suspect to furnish a handwriting sample, instead of searching for pre-existing specimens of his writing. In United States $v$. Rosato, ${ }^{71}$ the investigator went even further and had the suspected serviceman placed under a military order from his commanding officer to print the alphabet. On advice of counsel, the accused refused to comply with the order and was prosecuted before a court-martial for willful disobedience.

Even though the United States Manual for Courts-Martial, which is promulgated as a Presidential Executive Order, specifically authorized such an order, the Court of Military Appeals decided that it was illegal and constituted a violation of Rosato's privilege against self-incrimination. This and a subsequent military case, ${ }^{72}$ which decided that a handwriting sample obtained through use of a military order was inadmissible, seem to be almost unique in the United States in their consideration of the extent to which handwriting samples fall within the privilege against self-incrimination. ${ }^{73}$ Great reliance was placed on a Philippine case where the privilege against self-incrimination had been deemed to imclude handwriting samples. ${ }^{74}$ In a subsequent case, the Court of Military Appeals extended the same rationale to invalidate the conviction of an accused soldier who had been compelled to read some words aloud for the purpose of voice identification. ${ }^{75}$

These cases require especially close analysis of what the privilege against self-incrimination signifies. Certainly the handwriting or voice evidence that the investigator is seeking does not depend for its reliability on anything within the conscious control of the accused. The premise is that he simply cannot suppress all the natural traits of his handwriting, any more than he could alter the alcohol content of his blood

\footnotetext{
${ }^{71} 3$ U.S.C.M.A. 143, I I C.M.R. 143 (1953); 22 GEO. WASH. L. REV. 371 (1954).

${ }^{72}$ United States v. Eggers, 3 U.S.C.M.A. 191, 11 C.M.R. 19x (1953). See also 7 VAND. L. REv. 147 ( 1953 ).

${ }^{73}$ The Court of Military Appeals also cited a dictum in Dean v. United States, 246 Fed. 568 (5th Cir. 1917), and the holdiugs in Kennison v. State, 97 Tex. Crim. 154, 260 S.W. 174 (1924) and Cox v. State, 126 Tex. Crim. 202, 70 S.W.2d 1005 (1934). Subsequently, in United States v. Ball, 6 U.S.C.M.A. x00, 19 C.M.R. 226 ( 955 ), the court ruled that a suspect did not have to be warned of his right not to furnish a handwritiug sample since it was not a "statement." The Ball case was recently overruled in United States v. Minnifield, supra note 36 , one of many reversals of position that followed a change in Court membership.

${ }^{74}$ Beltran v. Samson \& Jose, 53 Phil. Is. 570 ( 1929 ).

${ }^{75}$ United States v. Greer, 3 U.S.C.M.A. 576, 13 C.M.R. ${ }_{32}$ (1953).
} 
or the narcotic content of his urine. Yet, it is clear that the conscious mind does play some role in producing either a verbal or written utterance, and that some characteristics of either writing or speech can be altered-even if not enough to deceive the qualified expert. Therefore, consciously or unconsciously, the suspect may be impelled to seek to disguise his writing or speech when an identification is attempted thereby. It is possible that any such disguise may itself be treated by the finder of fact as an admission of guilt-in which case, the suspect has testified against himself.

More important, the placing of the suspect in the position where he must choose between seeking to deceive the investigator and increasing the chance that he will be convicted is probably one of the very things against which the privilege against self-incrimination is directed. As previously noted, this may also be one of the reasons why many European countries do not allow the accused to be put under oath in a criminal trial. ${ }^{76}$ Is this another phase of a fundamental moral concept that the state should be prohibited from leading its citizens into temptation? $?^{77}$

On the other hand, there seems no risk in the present situation that an innocent man, under the prodding of the investigator's questions, will give an impression of guilt because he is not clever and glib in his answers. Instead, the assumption in the use by investigators of the handwriting or voice specimen is that the content of what is written or said is totally unimportant and that there are undisguisable characteristics which will inevitably distinguish the innocent from the guilty. On this assumption, there is absent one of the dangers against which the privilege against self-incrimination is directed.

Furthermore, to furnish a handwriting sample or read aloud from a book for purposes of identification does not give the interrogator a chance to pry into the suspect's secrets and to wring humiliating admissions from his own mouth-and, as many experienced cross-examiners would acknowledge, admissions from a person's own lips often have

\footnotetext{
${ }^{70}$ Not being placed under oath, the accused is freed from the choice between perjury and admission of guilt. Probably, too, it is considered that, in light of human nature, the administration of the oath to a defendant would often be a fruitless gesture.

${ }^{77}$ Of course, entrapment of a person by the police is generally considered to involve something more than presenting the opportnnity; the implanting of the idea of crime in the suspect's mind is also an important element. Thus, forcing an accused to speak could not be considered entrapment, as this term is generally used. Cf. Sorrells v. United States, 287 U.S. 435 (1932).
} 
more impact on that person and on others than when the same information comes from other sources. ${ }^{78}$

Although the compelling of a handwriting or voice sample does not involve many of the abuses from which the privilege against selfincrimination seeks to free the citizen, probably there is a sufficient residuum to justify the decisions which have applied the privilege in this context. ${ }^{79}$ This is all the more so, since in modern American society it is usually possible to obtain a specimen of a suspect's handwriting by checking various official files and registries. ${ }^{80}$

$\mathrm{V}$

\section{“Truth Drugs" and "Lie Detectors"}

In the popular press, among the more publicized instrumentalities for the detection of criminals are the so-called "truth serum"-drugs such as scopolamine, sodium amytal, and sodium pentothal-and the "lie detector," or polygraph, which seeks to discover deception by means of graphs recording physical responses associated with the answering of questions concerning a crime. In addition to its use in criminal investigation, the lie detector has been utilized by some private concerns and by several "sensitive" government agencies in screening employes.

Although both lie-detector and truth-serum results have generally been rejected as evidence in the United States, chiefly because of a claimed lack of reliability, the most vigorous denunciation of these investigative devices seems to have come from European sources. For example, after the use of drugs by French physicians to detect a malingerer, the Council of the Bar Association of the Court of Appeal of Paris adopted a resolution condemning the judicial use of narcoanalysis. ${ }^{82}$ This resolution emphasized that use of "truth serum"

${ }^{78}$ It is believed that psychiatrists would agree that sometimes admissions from a patient's own lips of certain past incidents can be a significant aspect of psychotherapy. Also, whether or not confession is good for the soul, certain theologians obviously place great emphasis on it.

${ }^{70}$ However, Professor Inbau, an outstanding expert in this area, seems to disagree. See INBAU, SELF-INCRIMINATION 46 (I950).

${ }^{80}$ E.g., an application for a driver's license signed by the suspect can often be located. Also, frequently a handwriting specimen can be obtained by a ruse or strategemapparently permissible police tactics in this setting.

${ }^{82}$ See People v. Davis, 343 Mich. 348, 72 N.W.2d 269 (1955); Highleyman, The Deceptive Certainty of the "Lie Detector," xo Hastincs L.J. 47 (1958); see also United States v. Haynes, 9 U.S.C.M.A. 792, 27 C.M.R. 60 (1958).

${ }^{82}$ See Gaugnieur, The Judicial Use of Psycho-Narcosis in France, 39 J. Crim. L., C. \& P.S. $66_{3}\left(x_{949)}\right.$. 
might involve violation of the physician-patient privilege and would constitute "an unbearable blow to the principle of inviolability of the human person." Furthermore, the statements and admissions of a person "which had been obtained under the influence of a pharmodynamic product, would be deprived of any probatory value in the legal sense."

The German Supreme Court in 1954 ruled on evidence obtained by a lie detector test which apparently had been administered with the defendant's consent. ${ }^{83}$ The use of such evidence led to reversal of the conviction because, apart from the usefulness of the polygraph in crime detection and the dependability of the scientific principles on which it rests, the court considered that it contradicted the inviolability of human dignity as guaranteed by the German Constitution. Although the trial court could properly conisider conscious and unconscious revelations on the part of the accused during the course of the trial, the scientific invasion of the accused's soul by means of the polygraph contradicted his right to freedom of decision and exercise of will.

A recent law review article expands the same concept and argues that to use truth serum or lie detectors, even with the consent of the accused, involves an invasion of the accused's personality and should never be allowed. ${ }^{84}$ Under the concepts presented in that article, it would contravene due process even to use the truth drugs or the lie detector prior to trial-much less to introduce the results of such tests in court. The consent of the person being tested would not alter the result, nor would the fact that the tests were used on a prosecuting witness instead of on the defendant. Presumably, if such tests should not be used even to exonerate an innocent accused with his own consent, it would be equally illegal to use them for screening employees and the like.

In the American cases, it generally has been the defendant who has attempted to use the results of truth serum or polygraph tests. As applied to such cases, the views just discussed would exclude the result of such tests, irrespective of their reliability. On the other hand, the focus of the American courts has been on the reliability or unreliability of the test-and this, in turn, implies an unwillingness to rule that the

\footnotetext{
${ }^{88}$ Decision of First Criminal Senate; German Supreme Court from District Court of Zweỉbrucken-5 B.G.H. St. 332, No. 78 (Feb. I 6, 1954): (1956).

${ }^{86}$ Silving, Testing of the Unconscious in Criminal Cases, 69 HARv. L. REv. $6 \dot{8}_{3}$
} 
evidence resulting from such tests must be held inadmissible in order to vindicate man's "dignity."

Apparently, it is thought that an accused's dignity will be better preserved by protecting him from an unjust conviction and possible death or confinement than by forbidding the probing of his unconscious mind. After all, if psychiatrists are allowed to probe the unconscious with drugs in preserving a patient from disease, is it so much worse to probe someone's unconscious to protect him from injustice?

One of the most recent instances of a defendant's effort to introduce in evidence truth-serum results occurred in State v. Sinnott. ${ }^{85}$ The defendant, who was accused of sodomy with a thirteen-year-old child, called as a witness a psychiatrist who had examined him twice prior to trial - the second time with the aid of sodium pentothal, a truth drug. The doctor proposed to testify that, in his opinion, Sinnott was not a sex pervert; but the evidence was excluded. The New Jersey appellate courts considered the offered testimony to be a form of character evidence, and yet not evidence that complied with the usual rules governing character evidence. To admit such evidence would, among other things, present the problem of the manner in which the prosecution could undertake rebuttal. Would it be permissible for the prosecution to rebut with evidence concerning specific acts of misconduct, or with testimony from any doctors who might consider the defendant to be a sex deviate?

In so far as the use of truth serum was concerned, the unreliability of results obtained thereby was emphasized in the Simnott case. ${ }^{88}$ Not every person tells the truth under the influence of drugs; many fabricate or indulge in fantasy, and frequently the subject is quite suggestible. Danger exists, therefore, that a truth-serum interview may be simply an opportunity for a defendant to make to a psychiatrist self-serving statements that are not subject to cross-examination. Then, if the psychiatrist is allowed to present his expert opinion and explain the basis therefor, these same statements may be repeated to the jury-at this point, surrounded by the atmosphere of credence created by their having been made under the influence of a "truth serum."

\footnotetext{
${ }^{85} 43$ N.J. Super. I, 127 A.2d 424 (1956), aff'd, 24 N.J. 408, 132 A.2d 298 (1957).

${ }_{88}$ Great reliance was placed on the conclusions reached in Dession et al., DrugInduced Revelation and Criminal Investigation, 62 YALE L.J. 315 (1953), an article often cited by the courts in connection with truth serum problems.
} 
Rejected by the New Jersey courts was the reasoning of People $v$. Jones, $^{87}$ a California decision on which Sinnott had especially relied. There, the facts were almost identical, and it was ruled that a psychiatrist should have been allowed to testify on the basis of two interviews with Jones-one under sodium pentothal-that the defendant was not a sex deviate and was incapable of forming a lustful intent. In so far as the truth-serum interview was concerned, the California court emphasized that its results were not being used to show the truth of defendant's assertion, but instead simply to show the basis for the expert's opinion.

Of some interest to the comparative lawyer is State v. Lindemuth, ${ }^{88}$ where, in rejecting truth-serum evidence offered by the defendant in a murder case to show that he did not kill the deceased, the New Mexico Supreme Court relied on an article concerning French experience with psychonarcosis. Oklahoma also considers truth serum results to be inadmissible-even where the defendant is willing, prior to the taking of the test, to be bound by the results. ${ }^{89}$

A military case presents an interesting factual variant. ${ }^{90}$ A naval officer was convicted by a court-martial on a charge of having raped a navy nurse. At the trial, he asserted that he suffered from alcoholic amnesia with respect to the crucial time period. Subsequently, however, he was examined by a psychiatrist who utilized a truth serum, and the transcript of the interview was attached to a petition for new trial submitted to the Court of Military Appeals. Needless to say, this transcript portrayed events in a way that was highly favorable to the defendant-although not to the prosecutrix. The petition was rejected, the court noting that a truth-serum interview is unreliable because of the ability of many subjects to lie despite the drug, and the tendency of others to be highly suggestible and engage in fantasy. In a subsequent case, however, the court did uphold the right of certain military officials, in reviewing a court-martial conviction, and in their unlimited

${ }^{87} 42$ Cal.zd 219, 266 P.2d 38 (1954). See also Curran, Expert Psychiatric Evidence of Personality Traits, ro3 U. PA. L. REv. 999 (1955); Falknor \& Steffen, Evidence of Character: From the "Crucible of the Community" to the "Couch of the Psychiatrist," 102 U. PA. L. Rev. 980 (1954); Note, 42 CALIF. L. REv. 880 (1954).

${ }^{88}{ }_{56}$ N.M. 257,243 P.2d 325 (1952).

${ }^{80}$ Henderson v. State, 94 Okla. Crim. 45, 230 P.2d 495 (x951), 23 A.L.R.2d 1292. Cf. State v. Hudson, 289 S.W. 920 (Mo. I926); Orange v. Commonwealth, Igr Va. 423, 6x S.E.2d 267 (1950); People v. Cullen, 37 Cal.2d 614, 234 P.2d I (1951).

${ }^{00}$ United States v. Bourchier, 5 U.S.C.M.A. I5, 17 C.M.R. 15 (1954). Cf. People v. McNichol, xoo Cal. App.2d 554, 224 P.2d 21 (x950), which involved amnesia. 
discretion, to consider truth-serum and lie-detector data that might be favorable to an accused.91 To this extent, then, probing the unconscious has been approved in military investigations.

In some instances, truth serum has been used by police in investigations. Among the best-known cases is that of William Heirens, who was apprehended in the course of a burglary and subsequently was interviewed while drugged. The interview revealed Heirens' commission of several murders and other crimes. As part of an agreement entered to avoid a death sentence, the defendant pleaded guilty to several crimes; but later, he tried to upset the conviction in a proceeding under the Illinois Post-Conviction Hearing Act. Although the questioning of Heirens under sodium pentothal and with a lie detector-in each instance without his consent-was denounced as a flagrant violation of his rights, the Supreme Court of Illinois considered that the plea of guilty was not the product of these tactics and so was valid. ${ }^{92}$

Sometimes a confession will follow the testing of an accused under truth serum. In such instances, the confession will, nonetheless, be received in evidence if the court concludes that it was not the product of the drugged interview. ${ }^{03}$ However, it can be inferred from a case involving a parallel situation that the United States Supreme Court will examine the facts carefully through the spectacles of "due process" to assure that there is absolutely no causal connection between the truthserum revelations and the ultimate confession..$^{94}$

In the investigation of sex offenses, it has been recommended by some that the prosecutrix be examined under a truth serum or with a lie detector. Lindsey v. United States, ${ }^{95}$ involves an interesting attempt by the Government to use in evidence the results of such examination. The defendant, who was being prosecuted for statutory rape and sodomy allegedly committed on his adopted daughter, sought to impeach her by proof of some previous inconsistent statements. To rehabilitate her, the prosecution called a psychiatrist to testify that, on the basis of various tests, he was convinced that she was not a liar but instead a normal girl and was telling the truth about the incidents with the defendant. After the witness explained the operation and reliability

\footnotetext{
${ }^{92}$ United States v. Massey, 5 U.S.C.M.A. 514, 18 C.M.R. 138 (1955).

${ }^{22}$ People v. Heirens, 4 IIl.2d I3 I, 122 N.E.2d 23 I (1954).

${ }^{98}$ Henson v. State, 159 Tex. Crim. 647, 266 S.W.2d 864 (1953).

'Leyra v. Denno, 347 U.S. 556 (1954), (confession following interview by one learned in hypnosis; the transcript of the interview is an appendix to the Court's opinion and resembles interviews in the course of narcoanalysis).

${ }_{95} 237$ F.2d 893 (9th Cir. 1956); see also Note, 1957 U. IL.L. L.F. 138 (1957).
} 
of sodium pentothal, a tape recording of an interview with the prosecutrix made while under the effect of this drug was received in evidence and replayed to the jury. A conviction ensued, but was reversed on appeal.

The Court of Appeals noted the increasing tendency of the courts to let psychiatrists testify about the credibility of witnesses-a tendency typified in the second trial of Alger Hiss by the trial judge's reception of a psychiatrist's testimony that he had observed Whitaker Chambers on the witness stand and had concluded that Chambers was a liar. ${ }^{96}$ However, in Lindsey, the appellate court reasoned that, even if it were permissible to let the psychiatrist testify as to the prosecutrix's credibility after she had been impeached and to refer to the sodium pentothal test as a basis for his expert opinion, it was, nonetheless, prejudicial error to admit in evidence the verbatim contents of the tape-recorded interview. The prejudice to defendant was heightened by references to the drug as a "truth serum" during the psychiatrist's testimony.

In a Florida prosecution for incest, it developed that the prosecutrix had at one time been mentally deranged..$^{97}$ To establish her credibility. it was brought out that she had been interviewed by a psychiatrist under sodium amytal and had reiterated the complaint. In reversing the subsequent conviction, the Florida Supreme Court relied on an analogous lie-detector case ${ }^{98}$ and reasoned that, once the truth-serum test was mentioned, defendant either had to cross-examine about the details or be damned by inference from his failure to do so. In effect, the defendant would be subjected to the results of a truth-serum test, even though such results are deemed too unreliable for admission directly into evidence.

The Florida courts have discerned the great difficulty in maintaining any line between mere reference to truth-serum tests and evidence concerning all the details of a truth-serum interview. And with the American jury system, there is always the chance that the twelve lay jurors will not comprehend the unreliability of truth serum and will conclude that it really guarantees truth. In that event, the fairness of the trial will depend on the efficacy of the test-always an imponderable.

For the investigator, truth-serum tests of a prosecuting witness may uncover some mental ailment that impairs his credibility. On the other

\footnotetext{
${ }^{06}$ United States v. Hiss, 88 F. Supp. 559 (S.D.N.Y. 1950).

${ }^{87}$ Knight v. State, 97 So.2d Ir 5 (Fla. 1957).

${ }^{88}$ Kaminski v. State, 63 So.2d 339 (Fla. 1952).
} 
hand, similar tests of a defendant may disclose that he does not have a purported mental disorder, on which he has hoped to hang an insanity defense. In one New York first degree murder prosecution, after the defendant had entered an insanity plea and asked that he be examined as to sanity, he was hospitalized. While in the hospital, he was interviewed under drugs. The New York Court of Appeals ruled that the evidence obtained by administration of the drugs-evidence which proved defendant to be a malingerer-could be used at the trial..$^{90}$ Having advanced a claim of insanity, defendant was subject to methods, including truth drugs, that are customarily used by the medical profession to determine one's mental condition. To soine, the authority of this precedent seems weakened by a subsequent New York decision which held inadmissible the defendant's proffered medical testimony about the results of a sodiun amytal test as it bore on ability to premeditate..$^{100}$

The decisions as to lie detectors follow the pattern of the truth-serum cases. Almost universally, lie-detector evidence is rejected in court as unreliable, ${ }^{101}$ although one New York trial court did allow the defendant to introduce evidence concerning the results of such a test. ${ }^{102}$ Moreover, in a California case, the prosecution was allowed to introduce the results of a lie-detector test, since the parties had agreed before trial that any results would be admissible. ${ }^{103}$

Among the most detailed recent analyses of the lie detector's capabilities is that furnished by the Michigan Supreme Court in People v. Davis. ${ }^{104}$ There, the defendant was on trial for murdering his wife by running over her with a car, and he sought to introduce evidence that a polygraph test verified his account that it was an accident. A leading

\footnotetext{
${ }^{80}$ People v. Esposito, 287 N.Y. 389,39 N.E.2d 925 (1942).

${ }^{100}$ People v. Ford, 304 N.Y. 679, I07 N.E.2d 595 (I952).

${ }^{102}$ See, e.g., State v. Casale, 150 Me. 310 , 110 A.2d 588 (1954); Hawkins v. State, 222 Miss. 753, 77 So.2d 263 (1955); People v. Davis, 343 Mich. 348,72 N.W.2d 269 (1955); State v. Pusch, 77 N.D. 860, 46 N.W.2d 508 (1950); People v. Porter, I36 Cal. App.2d 46I, 288 P.2d 56I (I955); State v. Lowry, I63 Kan. 622, 185 P.2d I47 (1947); 23 A.L.R.2d I306 (1950); Conrad, The Federal Courts' Break with Tradition, 2I F.R.D. I99 (1957); Koffler, The Lie Detector-A Critical Appraisal of the Technique as a Potential Undermining Factor in the Judicial Process, 3 N.Y.L.F. I23 (1957). However, one court has upheld dismissal of a police officer who refused to comply with an order to complete a polygraph test. McCain v. Sheridan, - Cal.2d -, 324 P.2d 923 (1958).

${ }_{102}$ People v. Kenny, 167 Misc. 51, 3 N.Y.S.2d 348 (Queens County Ct. 1938).

${ }^{103}$ People v. Houser, 85 Cal. App.2d 686, r93 P.2d 937 (1948). See also Parker v. Friendt, 99 Ohio App. 329 , 118 N.E.2d 216 (I954).

${ }^{104} 343$ Mich. 348,72 N.W.2d 269 (1955).
} 
criminal investigator, Dr. Lamoyne Snyder, testified for the defendant about the high reliability of the polygraph when properly operated and its widespread use. The court, however, cited authority to the effect that the instrument was by no means infallible and observed that many lie detector experts do not advocate the admissibility of polygraph results under current conditions. Among the other problems that bothered the court was whether, if the evidence were allowed as to one witness, it would have to be as to all-with the result that the case might be tried in the laboratory of the polygraph expert, instead of in the courtroom.

As with the truth serum, the prior use of a lie detector does not vitiate a subsequent voluntary confession ${ }^{105}$ indeed, in light of the suggestibility attributed to the recipient of a "truth serum," it would seem far easier to show that a confession following a lie-detector test was voluntary than would be true after an interview under drug influence. Also, as with truth serum results, the question arises of whether a witness's mention of a lie-detector test is improper. ${ }^{106}$ On the other hand, the lie detector does not have the same significance for investigation of mental ailments that truth serum does.

Both as to the lie detector and the truth serum, American courts have not warmly embraced the European-fostered view that under no circumstances can such investigative devices be used, because to probe a suspect's mind invades his "dignity," even if done with his consent. ${ }^{107}$ In America, apparently the investigator is free to use such tests on a willing suspect, and probably the test results would be received in evidence if the courts were satisfied of their reliability.

This approach, it is submitted, is, in the long run, more consistent with a true balance of values. If an accused wants to take a lie-detector

${ }^{105}$ Henson v. State, ${ }_{59}$ Tex. Crim. 647, 266 S.W.2d 864 (1953). See also Commonwealth ex rel. Riccio v. Dilworth, I79 Pa. Super. 64, II5 A.2d 865 (1955); Henderson v. State, 94 Okla. Crim. 45, 230 P.2d 495, 23 A.L.R.2d 1292 (195I); Webb v. State, - Tex. Crim. -, 291 S.W.2d 331 (1956) (where apparently polygraph results were unfavorable for the prosecution). But c.f. People v. Sims 395 Ill. -69 N.E.2d 336 (1946). Where a polygraph shows a defendant to be lying and he confesses, it is often difficult to keep results from a jury while proving the voluntariness of the confession. Tyler v. United States, I93 F.2d 24 (D.C. Cir. 1954); Gasway v. State, ${ }_{57}$ Tex. Crim. $647,{ }_{248}$ S.W.2d 942, cert. denied, 344 U.S. 874 (1952); Leeks v. State, 95 Okla. Crim. 326, 245 P.2d 764 (1952); People v. Aragon, 154 Cal. App.2d 646, 316 P.2d 370 (1957).

${ }^{100}$ Compare Kaminski v. State, 63 So.2d 339 (Fla. 1952), with State v. Shepperd, too Ohio App. 345, 128 N.E.2d 471 (1955), aff'd, 165 Ohio St. 293, I35 N.E.2d $34^{\circ}$ (1956), cert. denied, 352 U.S. 910 (1956).

${ }^{307}$ This view is presented by Silving, supra note 84 . 
or truth-serum test to exonerate himself and if it is shown that the results will be reliable, is it really consistent with the "dignity" of the individual to say that he is not qualified to make such a choice, and that instead the state has chosen that such tests shall not be performed? This argument as to "dignity" will be especially unpersuasive to a man who, by reason of an unjust conviction, is either executed or confined in prison. And how is the "dignity" of society served by the infliction of punishment upon innocent persons by reason of the exclusion of evidence that would tend to show innocence?

So long as any emphasis is placed by the criminal law on mens rea, the courts will be confronted with a problem of determining the accused's state of mind. ${ }^{108}$ Moreover, so long as insanity-which embraces both the conscious and unconscious mind-constitutes a defense, the courts must, to some extent, probe beyond the conscious mind of the defendant. Nor is all of this probing done by the consent of the defendant. For instance, he may be under observation, although he is unaware of it. And some of the defendant's actions that reveal his true state of mind are performed by him involuntarily. In short, day in and day out, judges and juries must, in fact, examine both the conscious and unconscious mind of a criminal defendant-often at times and in ways to which he has not specifically consented. Therefore, when a lie detector or truth serum is used to accomplish this examination in a more accurate and scientific way, it seems rather incongruous to say that an invasion of the defendant's "dignity" has taken place.

Indeed, many European judges who criticize the lie detector or truth serum would probably observe with great interest the behavior of an accused during his trial and would feel perfectly free to draw inferences from such behavior. ${ }^{109}$ In some instances, these inferences might rely on the same sort of physical reactions that are involved in the operations of a lie detector. ${ }^{110}$ These judges are not deemed to have improperly invaded the accused's mental processes. Yet, in these instances, the accused has not consented to the drawing of inferences from his behavior (unless his presence in the courtroom, which is often required by law, is considered to be such a consent), whereas a suspect

${ }^{208}$ For discussions of mens rea, see Jerome hall, General Principles of Criminal LaW ch. 5 (1947); Clark \& Marshall, LaW of Crimes ch. 3 (5th ed. 1952).

${ }^{100}$ See the German decision, note 83 supra.

${ }^{120}$ Quercia v. United States, 289 U.S. 466 (1933), involved the situation of a judge who not only believed that persons who wring their hands are liars, but also informed the jury to the same effect. 
who consents to a lie-detector test has willingly agreed to have inferences, favorable or adverse, drawn from his physical reactions. The latter, rather than the former, situation would seem more in accord with the protection of an accused's "dignity."

Also, it has been protested that to admit lie-detector or truth-serum evidence would destroy the right to a public trial, since the result of the trial is really predetermined in the examiner's office. If this be so, how can the trial of a defendant who pleads partial or total insanity be considered public? There the verdict will generally hinge on the testimony of psychiatrists who have examined the defendant extensively in their private offices long before the trial. Indeed, quite a few cases hinge on events that took place in a laboratory far away from judges or jury. ${ }^{111}$ And many an accused has been convicted because of a pretrial confession that was not prepared under public scrutiny. In short, the admission in evidence of lie-detector or truth-serum results would not destroy the defendant's right to a public trial any more than do many other types of evidence accepted in every court.

Perhaps the reliability of truth serum and polygraph will never be great enough to warrant judicial use of their results, even under the prevalent American approach to the problem. However, even today, their accuracy seems sufficient to justify pretrial use by investigators; and there seems to be no valid reason to discourage such use in the hands of qualified persons. The skill of the user of such investigative devices is so important to their accuracy that clearly not every investigator should be turned loose with a lie detector or truth serum. Indeed, some have suggested that as a prerequisite to admitting polygraph results in court, a licensing requirement should be adopted for the operators in order to assure their possession of minimal qualifications. Truth serum should be restricted in use to physicians and clinical pychologists; injections by others might even be considered to involve a battery, or perhaps the unauthorized practice of medicine.

In the unlikely event that the goal of infallibility were reached with either the lie detector or truth serum, it might then be urged that even an accused should be involuntarily subjected thereto. The rationale of any such suggestion would be that the privilege against self-incrimination and the right to due process are designed only to avoid an innocent man's convicting himself out of his own lips. For federal investigators, it seems

${ }^{111}$ This is true with reference to bloodtests, fingerprint comparisons, ballistics evidence, analyses of urine specimens, and many other types of scientific tests that play a prominent part in modern criminal law administration. 
impossible to reconcile such a position with the unqualified privilege against self-incrimination, since, upon proper analysis, both truth serum and polygraph require a "testimonial utterance" for their success. ${ }^{112}$ While state investigators in some jurisdictions are more immune than their federal counterparts to the limitations imposed by the privilege against self-incrimination, it seems highly probable that to test an unwilling suspect with truth serum or with the polygraph would deprive him of "due process." It has been emphasized that the trustworthiness of a confession does not assure that its procurement conformed with "due process"; and, by analogy, it does not appear that the accuracy of truth-serum or lie-detector results would protect them from attack, if the suspect was tested unwillingly. ${ }^{113}$

As to the use of truth serum, at least one court-on the basis of a waiver theory-has taken a different tack where the defendant relied on insanity. ${ }^{114}$ Whether the interposition of an insanity plea constitutes a waiver of any privilege against administration of truth serum is only another phase of the general problem of waiver of the privilege against self-incrimination under such circumstances. ${ }^{115}$ Of course, this problem is complicated by the circumstance that if a defendant is genuinely insane, his competency to waive any right would be questionable.

In theory, proof of insanity at the time of the offense destroys the mens rea which is required for the commission of crime; on this premise, it should be treated just like any other element of the crime. However, the criminal law clearly has differentiated the sanity question from other problems of guilt. For instance, the presumption of sanity is generally recognized, though there is no presumption of guilt. ${ }^{116}$ And as to sanity, the allocation of burden of proof between prosecution and defendant may be different than with the usual questions of guilt or innocence. ${ }^{117}$ Where sanity at the time of trial, rather than at the time of the crime, is involved, again special provision is made; for instance, many jurisdictions authorize extensive pretrial hospitalization for observation of an offender whose sanity is questionable. ${ }^{118}$

\footnotetext{
112 See note 20 supra.

${ }^{113}$ As noted above, trustworthiness does not allow admission of a coerced confession. See, e.g., Rochin v. California, 342 U.S. 165 (1952).

${ }_{116}$ People v. Esposito, 287 N.Y. 389,39 N.E.2d 925 (1942).

${ }^{215}$ GutTMaCher \& Weihofen, Psychiatry aNd the LaW, 257 et seq. (1952).

120 See United States v. Biesak, 3 U.S.C.M.A. 714, 14 C.M.R. 132 (1954), for a detailed discussion of the sanity presumption.

${ }^{117}$ See Leland v. Oregon, 343 U.S. 790 (1952).

${ }^{118}$ GutTMACHeR \& WeIHOFEN, op. cit. supra note 115 , at 284 et seq.
} 
The uniqueness of the sanity issue has been recognized by the courts to such a degree that a strong plea can be made to discard usual concepts of self-incrimination where investigation of an accused's sanity is proposed. This argument would support the use of truth drugs or any medically-recognized technique for discovering state of mind. A rationale might be proposed-along the lines of the Esposito case ${ }^{119}$ that a defendant, if insane at the time he is mentally examined, will be conclusively presumed to have consented to the use of truth drugs by a qualified psychiatrist or psychologist, since such use will lead to the discovery of his true mental condition, and this, in turn, will redound to his benefit. On the other hand, if the accused is sane at the time of his examination, he is required to submit to truth serum or other recognized methods of psychiatric evaluation as a condition to presenting any insanity defense. Actually, such a rationale amounts to little more than saying that in so far as an insanity defense is concerned-whether it be insanity at the time of the offense or at the time of trial-there simply is no privilege against self-incrimination or against the administration of truth drugs and the like.

If any such argument is to be accepted, the courts must take care to assure that any incriminatory revelations to the psychiatrist by the accused not be communicated to the police and, a fortiori, that they not be used in evidence. In some instances, the psychiatrist may be limited by this restriction in expressing the predicate for his opinion, but any other result would reduce the privilege against self-incrimination to a shambles. Indeed, the police.in that event might make it a routine practice to investigate sanity through the vehicle of a psychiatric examination under truth serum. Of course, at any trial, the defendant's counsel would still be free to elicit from the witness the contents of any factual revelations by his client.

Some will insist that no matter how reliable a truth serum or lie detector may become, the suspect will be deprived of his privilege against self-incrimination if the tests are made of the witnesses against him. According to this argument, if witnesses against the accused are examined with such devices and are corroborated thereby, then the accused is impliedly forced to take the same tests in order to exonerate himself. In so far as the pretrial investigation is concerned, this argument seems unrealistic. As a practical matter, many an accused is

\footnotetext{
${ }^{110}{ }_{28}$ N.Y. 389,39 N.E.2d 925 (1942).
} 
forced to break silence during an investigation as reliable evidence piles up against him, and there seems little room for complaint on his part as to the obtaining of such evidence by the administration of tests to other persons..$^{120}$

If in some way it is brought out in evidence that the prosecution witnesses have "passed" a truth-serum or lie-detector test, the dilemma of the accused obviously is heightened. In so far as the results of such tests are not admissible in evidence, either directly or as a predicate for a psychiatric opinion as to credibility, ${ }^{121}$ any reference to the taking of the test should be held improper. ${ }^{122}$ Indeed, it seems best to exclude mention of a test, even if the results would on some theory be admissible, unless, in fact, they are admitted in evidence. However, in a jurisdiction that has determined that the results of a truth-serum or liedetector test are reliable enough to be admissible for the purpose offered, then it is submitted that the defendant has no more of a just complaint than in any other instance where the presence of strong evidence against him forces him to come forward with some explanation. If he does not wish to take a lie-detector test or truth-serum test himself, let him bring out by cross-examination or independent evidence the unreliability of the tests used on prosecution witnesses as to which evidence has been admitted.

In jurisdictions which recognize a patient-physician privilege, ${ }^{123}$ an effort may be made to invoke it in some cases with reference to truthserum results. However, it is probable that such situations will generally fall outside the policy of this privilege, which seems designed chiefly to instill confidence of the patient in the sanctity of disclosures he is making for medical, rather than investigative, purposes. ${ }^{124}$ Actually the administration of truth serum by a physician should not in itself affect the operation of the patient-physician privilege one way or the other.

Some jurisdictions permit a defendant who takes the stand to be questioned as to his silence or his plea of self-incrimination on previous

${ }^{120}$ The accused has no standing to complain, for his own rights have not been violated. Cf. Goldstein v. United States, 316 U.S. $\times 14$ (1942).

${ }^{121}$ See Lindsey v. United States, 237 F.2d 893 (9th Cir. 1956).

${ }^{122}$ See Kaminski v. State, 63 So.2d 339 (Fla. x953); Knight v. State, 97 So.2d

II5 (Fla. x957); People v. Carter, 48 Cal.2d 737, 312 P.2d 665 (1957).

${ }^{123}$ See 8 WIGMORE, op. cit. supra note $\mathrm{I}$, $\$$ \$ $2380-91$.

${ }^{126}$ Id. $\S 23802$. 
occasions. ${ }^{125}$ Would it be permissible to ask a defendant on crossexamination whether he had refused to take a lie-detector or truth-serum test? Certainly, with both investigative techniques in their present fallible state, such a question would seem of very dubious propriety. The refusal to take the test may be the result not of consciousness of guilt, but, instead, of ignorance concerning the test's administration, distrust of the operator's ability or integrity, and, with truth serum, fear of possible physical or psychological aftermaths. Of course, it can be said that the defendant can explain to the jury his reasons for declining the test; but, on balance, probably the best course would be to prohibit this whole line of cross-examination. Even as to witnesses other than the defendant, it should certainly be within the discretion of the trial judge to prohibit such questioning in order to avoid getting too far from the main issues of a trial.

A defendant may claim that he was deprived of a fair trial because he was denied the opportunity for a lie-detector or truth-serum testeither of himself or of certain witnesses. Certainly, the courts will be unwilling to accept such a claim until such tests have become more reliable; since the test results could not be used as evidence in most instances, the courts would hardly be willing to reverse a convictior because of any refusal of the prosecution to give the tests. ${ }^{126}$ Of course, as the accuracy of such investigative techniques increases, some legislatures may decide to require that they be used at the defendant's request in certain instances-regardless of whether the results would be directly admissible in evidence. However, without legislative action, the accused's chance of success is poor.

Where the accused's mental condition is at issue, he might urge that the failure to provide for the testing of that condition by all available means, including narcoanalysis, deprived him of "due process" and even of his "right to counsel." As to requests to test prosecution witnesses, he might insist that, to have the full benefit of court process in securing evidence, at his request such witnesses should be scientifically tested; and that to deny such a demand deprived him of his rights as

${ }^{135}$ Compare Grunewald v. United States, 353 U.S. 39 I (I957), with Raffel v. United States, 27 I U.S. $494(1926)$. See also 8 WIgmore, op. cit. supra note II $\S$ 2273.

${ }_{126}$ Cf. People v. Porter, ${ }_{3} 6$ Cal. App.2d 46r; 288 P.2d 56r (1955); Commonwealth v. Dilworth, I79 Pa. Super. 64, I 15 A.2d 865 (1955); State v. Perlin, 268 Wis. 529,68 N.W.2d 32 (1955). Nor would a court grant a petition for a new trial based on lie-detector or truth-serum evidence. United States v. Bourchier, 5 U.S.C.M.A. 15, 17 C.M.R. ${ }_{5}$ (1954). 
much as to refuse him court aid in subpoenaing witnesses. The tendency in recent years has been to put more and more of a burden on the government; ${ }^{127}$ but-in part because of probable solicitude for the welfare of prospective witnesses-it seems doubtful that courts would accept the defense position on this point, even if satisfied of the infallibility of the lie detector or truth serum.

In the event that a judge were willing to order that prospective witnesses be subjected to a truth-serum or polygraph test, what would be the validity of such an order? Not infrequently, this would involve a possible deprivation of the witness' own privilege against self-incrimination, ${ }^{128}$ although there might be some question as to the proper procedure by which the witness could vindicate his privilege. ${ }^{129}$ Sometimes the witness might have to resort ultimately to a criminal prosecution or a civil suit initiated against the persons who subjected him to the test against his will. Even apart from self-incrimination problems, a judge, as against proper objection, would probably be unwilling to force a witness to be examined under truth serum and, perhaps to a lesser extent, would hesitate to force submission to a lie-detector test. The only recourse, then, for the defendant would be the possibility of bringing out by cross-examination the witness' refusal to be tested. ${ }^{130}$

A defendant will often seek to bring to the jury's attention the circumstance that he volunteered for a lie-detector or truth-serum test. Actually, the volunteering may have been simply a last-ditch maneuver by a guilty man. ${ }^{131}$ At best, it is only an implied pretrial assertion of innocence and would be admissible in evidence only under circumstances when a prior consistent statement by a witness would be admissible. ${ }^{132}$

\footnotetext{
${ }^{123}$ For a typical case, see Griffin v. Illinois, $35 x$ U.S. 12 (1956).

${ }^{128}$ Not only would there be the possibility that the witness might be incriminating himself as to the offense under investigation, but also as to some offense predicated on false information previouly furnished.

${ }^{129}$ The witness, not being a party to the criminal proceeding against the accused, would have no standing to make a motion in the cause. On the other hand, he might seek an injunction, or a writ of prohibition, or mandamus, according to the procedure of the particular jurisdiction. If he were being held in custody to be tested, a writ of habeas corpus might be the appropriate relief.

${ }^{180}$ See note 125 supra for some relevant authorities. There is probably more reason to permit such cross-examination of a witness tban of a defendant, since with the defendant there is always the risk that a jury will "penalize" him for his refusal to cooperate with investigators by inferring guilt too readily.

${ }^{131}$ This point is made in Highleyman, supra note $8 \mathrm{x}$; See also People v. Parrella, - Cal.2d -, 322 P.2d 83 (1958); Commonwealth v. Saunders, 386 Pa. I49, 125 A.2d 442 (1956).

${ }^{132}$ See 4 WIGmore, op. cit. supra note 11, $§$ Ix22-44. North Carolina is ap-
} 
Even then, such evidence might properly be excluded in the court's discretion, on the ground that it would unduly distract and mislead the jury.

\section{VI}

Electronic Eavesdropping and Wire Tapping

The investigative measures discussed above bear rather directly on the person of the suspect. Electronic eavesdropping-especially through wire tapping -is a technique that ranges more widely. A survey of the cases reveals a frequent shifting of position by the courts with reference to such methods.

In Olmastead v. United States, ${ }^{138}$ the Supreme Court held by a 5-4 majority that the tapping of telephones without a trespass on defendant's property did not involve a "search and seizure" and so did not fall within the fourth amendment. This decision is an important precedent for limiting the scope of the fourth amendment. Had the decision gone the opposite way, legislation to authorize any type of wire tapping would, in effect, have been permanently precluded. Even under a warrant, one cannot search for and seize mere "evidence," and in most instances, it would be difficult to deem telephone conversations either the "tools" or "fruit" of crime. ${ }^{134}$

Relying on the subsequently-enacted section 605 of the Communications Act, which forbids any person to "intercept and divulge" the contents of a telephone message without the consent of the sender, the Court later held that it was unlawful for federal investigators to tap and use in evidence a telephone conversation or information obtained from the wire tapping. ${ }^{135}$ Even intrastate calls were within this prohibition. ${ }^{136}$

Then the tide turned again. It was held permissible to utilize a detectaphone which overheard everything said by a suspect, including what he said into his telephone. ${ }^{137}$ A defendant was denied standing to

parently more willing than most jurisdictions to allow corroboration by a prior consistent statement.

${ }^{133} 277$ U.S. 438 (1928).

${ }^{134}$ Supra note 23 .

${ }^{238}$ Nardone v. United States, 302 U.S. 379 (1937), following re-trial, id., 308 U.S. 338 ( 1939 ).

${ }^{130}$ Weiss v. United States, 308 U.S. 32 I (1939).

${ }^{137}$ Goldman v. United States, 316 U.S. I29 (1942). Cf. On Lee v. United States, 343 U.S. 747 (1952), where an informer used a hidden microphone while talking to the defendant. 
protest that investigators had obtained information through tapping someone else's wires. ${ }^{138}$ A state court was ruled to be free to use wiretap evidence, even though such evidence had been obtained in violation of a federal statute. ${ }^{139}$ In Irvine v. California ${ }^{140}$ the evidence revealed that investigators had entered the accused's house and installed a microphone. Under the principle that a state court can determine whether to consider illegally-obtained evidence, the Supreme Court ruled that the evidence was properly admitted. Nor was a deprivation of "due process" deemed to be present, since here the injury was not to the defendant's person, as in the Rochin case, ${ }^{141}$ but only to his privacy, because of the trespass and eavesdropping. Although it was explicitly proposed by two of the justices that there be federal prosecution of the investigators for violation of Irvine's constitutional rights, the other justices seemed unwilling to move so directly into the enforcement of protection against investigative excesses.

The Supreme Court, at its last term, handed down two more decisions on wire tapping. In one, it was ruled that for a police officer to listen in on a phone conversation with the consent of one of the participants did not constitute the "interception" proscribed by section $605 .^{142}$ However, Benantiv. United States, ${ }^{143}$ has cast a pall on the wire tappers. - In that case, cross-examination of state investigators who were testifying for the prosecution revealed that they had acquired some of their information from wire tapping. The Supreme Court ruled that even though the illegality was that of state rather than federal officials, these investigators should not be allowed to divulge to a jury information which they had obtained in this matter. Although refusing to rule whether violation of section 605 requires both an interception and

${ }^{188}$ Goldstein v. United States, $3 \times 6$ U.S. $\mathrm{I}_{4}$ (1942).

${ }^{189}$ Schwartz v. Texas, 344 U.S. 199 (1952). Naturally, the Court in this case placed great emphasis on Wolf v. Colorado, 338 U.S. 25 (I949), where state courts were held to be free to use evidence obtained by illegal search and seizure. To avoid the effect of the Schwartz case, one defendant in a state court sought a federal court injunction, to be based on the Communications Act, which would enjoin the admission of wire-tap evidence and would require destruction of the recordings of his conversations. However, the requested relief was considered by the federal courts to involve undue interference with state criminal procedure. Voci v. Farkas, 144 F. Supp. 103 (E.D.Pa. 1956); Voci v. Storb, 235 F.2d 48 (3d Cir. 1956). If wiretapping by a federal officer had been involved, relief would probably have been forthcoming. Rea v. United States, 350 U.S. 2 I4 (1956) (illegal search and seizure).

${ }^{160} 347$ U.S. 128 (1954).

141342 U.S. 165 (1952).

${ }_{142}$ Rathbun v. United States, 355 U.S. 107 (1957).

${ }^{143} 355$ U.S. 96 (1957). 
divulgence of a telephone conversation, the Court held that the testimony by the state investigators would certainly constitute a violation of section 605. To permit the United States to prosecute a defendant with testimony the giving of which constituted a federal crime would, in the Supreme Court's eyes, not give sufficient weight to statutory policy.

Another facet of the case is of interest. The investigators were wire tapping under the authority of a New York state court order entered pursuant to that state's constitution and statutes. However, in light of its conclusion that section 605 had pre-empted the field as to interception of telephonic communications, the Supreme Court concluded that New York had no power to authorize wire tapping.

An interesting question now concerns the extent to which the laws of New York and of other states with wire-tap legislation will permit the use of wire-tap evidence in the courts of those states. ${ }^{144}$ Will those courts continue to grant their police the authority to wire tap in the face of the Court's determination that state legislation providing for wire tapping invades an area pre-empted by the Federal Government through the Communications Act? In light of the unpopularity of the whole pre-emption doctrine in some states, this course of action is by no means impossible. ${ }^{145}$

In those states where, as at common law, the manner in which evidence is obtained does not affect its legality, it may be difficult to test this point, since the order for wire tapping is obtained ex parte in the first instance, and later, at any trial, it will be unnecessary to inquire into the legality of such an order. Even states which by statute or by judicial decision have departed from the common-law rule of admissibility as to the products of an illegal search and seizure ${ }^{\mathbf{1 4 6}}$ might hold that this departure was limited to searches and did not embrace wire tapping-which is not a "search and seizure."147 Of course, at some point, the Supreme Court might decide to intervene by overruling its

${ }^{146}$ State legislation is summarized in Westin, The Wire-Tapping Problem, 52 Colum. L. REv, 165, 181 (1952). Westin also discusses the New York experience under its legislation, which authorizes wire tapping under court order. Id. at 192.

${ }_{145}$ The pre-emption doctrine, as reflected in cases such as Pennsylvania v. Nelson, 350 U.S. 497 (1956), and Amalgamated Association v. Wisconsin Employment Relations Board, 340. U.S. 383 (1951), was recently criticized severely by the Conference of Chief Justices at their August, $195^{8}$ meeting. See U.S. News and World Report, Oct. 3, 1958, pp. 92-102.

140 Supra note 10.

${ }^{147}$ See Olmstead v. United States, 277 U.S. 438 (I928). 
holding that the Communications Act does not preclude state court use of wire-tap evidence. ${ }^{148}$

The person whose wires have been tapped by investigators or others may seek to have federal criminal prosecution instituted or to bring a civil suit for invasion of privacy. Federal prosecutions for wire tapping have not been numerous in the past, ${ }^{149}$ and there is no guarantee of a great willingness to undertake them in the future. As for civil actions, not every jurisdiction even recognizes a right of privacy; and in any event, a substantial recovery might be hard to come by if the investigator had acted under a court order-even if that order may have been a nullity by reason of the Communications Act. ${ }^{160}$

The possibility of criminal prosecution may lead investigators to plead self-incrimination when cross-examined as witnesses about the use of wire-tap apparatus. In a federal court, this privilege would merit recognition. On the other hand, in the court of a state which had no penal law against wire tapping, the person pleading self-incrimination would face the argument that a state court should only recognize selfincrimination with reference to possible state penalties, not federal ones. ${ }^{151}$

Congress has recently been urged to overturn the principle of several Supreme Court decisions that certain state statutes have been superseded by federal "pre-emptive" legislation. To limit further Court holdings

${ }^{248}$ Schwartz y. Texas, 344 U.S. 199 (1952).

${ }^{160}$ One writer states that there has been only one reported case involving wiretapping. Donnelly, Comments and Caveats on the Wire Tapping Controversy, $6_{3}$ YALE L.J. 799, 802, n. 20 (1954). See also Westin, supra note 144, at 169 . The Teamsters' Union leader, James Hoffa, recently emerged unscathed from a wiretapping trial. On the other hand, the writer is aware of a case tried in the Federal District Court for the Middle District of North Carolina, at its March 1957 term, which did result in a conviction and fine after a nolo contendere plea. United States v. Atkins and Stallings. This case was all the more unusual since one of the defendants was a County Chairman of the Democratic Party. Some might suspect that in this case and in the Hoffa prosecution there were at least some political overtones.

${ }^{200}$ Certainly, the order, as evidence of good faith, would help negate a claim for punitive damages. One question that might be considered is whether a federal court has civil jurisdiction to entertain an action for damages based on an alleged violation of $\S 605$ of the Communications Act, 48 STAT. 1103 (1934), 47 U.S.C. 605 (1952). If there is such a right, what is the measure of damages? If a civil suit is predicated on an alleged violation of privacy in a jurisdiction which recognizes the right of privacy, the measure of damage is still a problem, especially where there is no proof that the tapped conversations were divulged by the investigator. Incidentally, with the new improved techniques for wiretapping with induction coil units, it would be unusual for the wiretapper to be guilty of trespass in the traditional sense.

${ }^{151}$ See 8 WIGMORE, op. cit. supra note 11 , § 2258 . 
along these lines, it has been proposed that Congress declare that its enactments should not be interpreted as pre-empting a field of legislation unless there is evinced a clear intent so to do. Should some such rule of construction be promulgated, the future of state-authorized wire tapping would brighten considerably, and the holding of the Benanti case as to the effect of the New York authorization of wire tapping would be imperiled.

Congress has also heard many proposals for the amendment of the Communications Act to allow wire tapping by federal law agents in certain types of cases and under certain conditions; ${ }^{152}$ but the chances of passage of any such proposals do not seem good at the present time. Should the pre-emption legislation be enacted and restore to the states the power to authorize wire tapping and no amendment be made to the Communications Act, the ironic result will be that federal law agents, confronted with some of the most dangerous offenses, such as espionage will have no right to tap wires under any conditions, while a local policeman may be in a position to wire tap in investigating a relatively innocuous offense. To heighten the irony, the likelihood that federal agents would misuse the products of wire tapping for private purposes, such as blackmail, seems substantially less than that police officials at other governmental echelons might do so. ${ }^{163}$

Of course, in determining the methods that should be available to the federal investigator as compared with other law enforcement agents, one cannot overlook the risk of totalitarianism that always lurks in the background where there is a "national" police force. ${ }^{154}$ In connection with some investigative techniques, this risk is really insignificant. For example, if federal investigators are allowed to make compulsory bloodtests of suspects, there is no increased likelihood that this will speed the coming of a dictatorship in the United States. However, with wire tapping and the indiscretions and secrets it discloses-sometimes of considerable political import-there can be little doubt of the potentiality

${ }^{152}$ See, e.g., Rogers, The Case for Wire Tapping, 63 YALE L.J. 792 (1954); Westin, supra note 144 , at 202 .

${ }^{163}$ Certainly, it is the writer's impression that federal investigative agencies have been less subject to scandal in the past than other investigative groups. Of course, state and local standards of criminal investigation seem to be continually improving.

${ }^{186}$ Frequently, it is not realized that England has no "national police force" and that even the fabled Scotland Yard has jurisdiction only in the London area, unless requested for assistance by other English police forces. See, e.g., Harrison, op. cit. supra note 5 x. 
for misuse to help centralize power in the hands of a dictator or small group.

How real is this menace? Among its antidotes is the high professional standard now set for their investigators by the Federal Bureau of Investigation and other federal agencies. ${ }^{155}$ This standard has its counterpart in several European and other countries where the penalties for misconduct by a policeman can be quite severe. Another safeguard is the division of investigative jurisdiction among several federal agencies, and the limitation of the Federal Government to the detection and punishment of only those crimes with "federal" significance, others being punished by state agencies. Against this institutional background, the dangers to democracy from a "national" police force seem exaggerated.

There is another strong argument that supports proposals to legalize some federal wire tapping, whether or not state investigators are allowed to tap wires. At the present time, it seems clear that some wire tappir. is being done by the Federal Bureau of Investigation. ${ }^{158}$ Apparently, a major motivation for this wire tapping has been a belief that it was an essential instrumentality for detecting certain dangerous enemies. society, such as spies. Convinced of the necessity to tap wires in certain cases where national security is at stake, the FBI agent feels morally. justified in tapping the wires in such instances. It is unlikely that he will be dissuaded by any statute from tapping wires in a case where he feels that such investigative methods are essential. Thus, he is throwin in conflict with some of the very laws that he is called upon to defend. Aside from the diffculties of conscience that this entails, this conflict lowers him in the eyes of the community. Moreover, having once tapped wires in the interests of necessity, the investigator may find "necessity" to be a relatively flexible concept in subsequent investigations.

On the other hand, to provide the investigators with authority to tap wires in certain well-defined instances-particularly those involving espionage or sabotage-where the arguments of necessity are especially

${ }^{265}$ Admittedly, police forces with a very high professional standard in some respects can become engines of totalitarianism. This seems to have been true in Nazi Germany and elsewhere, efficiency having been united with tyranny. However, this writer has been unable to discern a real danger in that respect in this country, in so far as federal investigators are concerned.

${ }^{250}$ This came to light in the Judith Coplon prosecutions. United States v. Coplon, 191 F.2d 749 (D.C. Cir. 195I), cert. denied, 342 U.S. 926 (1952); United States v. Coplon, 185 F.2d 629 (2d Cir. 1950), cert. denied, 342 U.S. 920 (1952). See also Westin, supra note 144 , at 169 . 
convincing ${ }^{157}$ may reduce considerably the pressure for the federal agent himself to utilize a prohibited investigative technique. And, as one writer points out, it may induce the Federal Government to institute more wire-tapping prosecutions-a course of action difficult to adopt when federal agencies are themselves engaged in illegal wire tapping. ${ }^{158}$

The criticism will be voiced that this argument involves a lowering of legal standards to accommodate the illegality of the investigator and a failure to utilize the law to elevate standards of behavior. Still, even the power of law to reform police behavior can only be exercised within reasonable bounds; and the limitations today on federal wire tappir: may have somewhat transcended those bounds.

\section{VII}

\section{Conclusion}

For the most part, the investigator, using new scientific techniques, has not been unduly handicapped by the courts, although as to wire tapping, some mitigation by Congress of the legal restrictions on federal agents would probably be helpful. Legislation at either the federal or state level might also be desirable: to impose restrictions on access to information from police fingerprint and photograph files; to require the licensing of polygraph operators; and to provide more expressly for the circumstances under which body fluids can be obtained from a suspect.

In a few instances, the courts have reached unfortunate results in this field-chiefly when they departed from usual American practice and relied on sweeping generalizations, instead of piecing out solutions on a case-by-case basis. However, as of today, a reasonable balance seems to exist between the need of society for efficient law enforcement and the needs of the individual to have some area of privacy and of protection against humiliation or pain at the hands of the police.

${ }^{207}$ See Rogers, supra note 153 ; Westin, supra note 144. But cf. Donnelly, supra note 149; Schwartz, On Current Proposals to Legalize Wire Tapping, ro3 U. PA. L. REv. I 57 (1954).

${ }^{269}$ Westin, supra note 144 , at 169 . Of course, the Department of Justice does not seem to consider that its wire tapping is illegal. Id. at 179. 